\title{
Yunus Emre Şiirlerinin Türkçeden Fransızcaya Çevirisinde Sözdizimsel Girişimler
}

\section{Syntactic Initiatives in the Translation of Yunus Emre's Poems from Turkish to French}

\author{
Yusuf Polat ${ }^{1}(1)$
}

${ }^{1}$ Kırıkkale Üniversitesi, Fen Edebiyat Fakültesi, Batı Dilleri ve Edebiyatları Bölümü, Türkiye

ORCID: Y.P. 0000-0001-9341-6643

Sorumlu yazar/Corresponding author: Yusuf Polat,

Doç. Dr., Kırıkkale Üniversitesi, Fen Edebiyat Fakültesi, Batı Dilleri ve Edebiyatları Bölümü, Türkiye

E-mail: polatyus@gmail.com

Bașvuru/Submitted: 05.11.2020

Revizyon Talebi/Revision Requested: 03.12.2020 Kabul/Accepted: 29.12 .2020

\section{Atıf/Citation:}

Polat, Y. (2021). Yunus Emre şiirlerinin Türkçeden Fransızcaya çevirisinde sözdizimsel girişimler. TUDED, 61(1), 411-445.

https://doi.org/10.26650/TUDED2020-821665

\section{ÖZET}

Çeviri uygulamacıları yazınsal söylemin çevirisinin daha güç bir etkinlik olduğunu bilirler. Bu güçlük girdinin sesbilimsel, sözcüksel ve sözdizimsel özelliklerinin yanı sıra, anlamsal ve kültürel boyutları ile de doğrudan ilişkilidir. Şiirde biçim ile içerik ayrılmaz bir bütün oluşturduklarından birinin öteki lehine göz ardı edilmesi şiirin doğasına zarar verebilmektedir. Bu yönüyle şiir çevirisi çevrilebilirlik tartışmasına da konu edilmektedir. Tartışma taraflarının büyük bir bölümüne göre de șiir çevrilemeyen bir söylem türüdür. Türk şiirinin evrensel halk şairlerinden Yunus Emre'nin şiirleri birçok dile çevrilmiştir. Diğerleri arasında bu çeviriler Fransızcaya Tahsin Saraç tarafından yapılmıştır. Bu çalışmada öncelikle şiir söyleminin genel özelliklerinden söz edilmekte, şiir çevirisi ana çizgileriyle betimlenmekte ve çeviriyi yazınsal bakış açısıyla açıklamaya çalışan yaklaşımlar kısaca tanıtılmaktadır. Son aşamada Tahsin Saraç tarafından yapılan şiir çevirilerinde kullanılan çevirmen girişimlerinin bir dökümü yapılmakta ve örneklendirilmektedir.

Anahtar Kelimeler: Çeviri, Şiir çevirisi, Çeviri stratejileri, Yunus Emre, Tahsin Saraç

\section{ABSTRACT}

Translation practitioners know that translating literary discourse is a relatively difficult activity. This difficulty is directly related to the phonological, lexical, and syntactic features of the input as well as its semantic and cultural dimensions. Poetry is a particularly difficult type of text; since form and content create an inseparable whole in poetry, one cannot be ignored or sacrificed in favor of the other. Many scholars even argue that poetry is a type of discourse that cannot be translated. The poems of Yunus Emre, one of the universal folk poets of Turkish poetry, have been translated into many languages, including French translations by Tahsin Saraç. This study first identifies the general features of poetry discourse and then describes poetry translation from a literary perspective. The second part of the study analyzes the translations by Tahsin Saraç.

Keywords: Translation, Poetry translation, Translation strategies, Yunus Emre, Tahsin Saraç 


\section{EXTENDED ABSTRACT}

The approaches used by translators and the decisions they make when converting any source language input to target language output are called methods or strategies in the scientific literature of translation. In this study, the sentence-level translation preferences adopted by the translator, specifically for poem inputs translation, are examined. Thus, following the comparative description of the source language text and the target language text, we reviewed data in the form of 10 poems belonging to Yunus Emre, translated by Tahsin Saraç in 1973. We felt the data obtained from this research may be useful in creating resources that can be developed for the training of translators.

First, brief information about poetry as an input type is given in the study, and the different points of view regarding untranslatable poems are identified. The translation of poetry presents serious difficulties as it is a genre in which the relationship between form and content is particularly important; however, it is also highlighted that many poets are internationally recognized, owing to the outstandingly successful translations of poetry in the historical process.

After the poetry translation methods, the translation strategies known in the literature are summarized. To this end, semantic and communicative translation methods, translation approaches at lexical and supra-lexical levels, and the concepts of direct and indirect translation processes are explained.

In the section where research information is given, some studies on the translation of Yunus Emre's poems are briefly presented to determine what interventions were made at the sentence level. (Our study does not address translation criticism.) In addition, the translator's strategy choices are limited only at the syntactic level. In other words, the translator's attempts to affect the level of the sentence have been taken into account.

Some of the results obtained from the sentence-level descriptive research relate to the formal aspect of the poem, with a significant part involving translations aimed at the verb groups. The translator has chosen to translate all of the poems with two or four strings in the source text as two strings.

Another finding concerning the formal dimension of the poems in our database is related to rhymes. Saraç had to reduce a significant part of the rhymes included in all the source poems. This indicates that the translator focuses more on the dimension of the message and meaning in the poems than on the poem construction.

As for Saraç's attempts at the syntactic level in translations of poetry, the first is based on changing the mode of action in the source text. The transformation from imperative in the source language to indicative in the target language and vice versa is one of Saraç's preferences. Another type of intervention is the transformation of the verb in the infinitive to a conjugated verb. 
Some of these examples include the reduction of the verb -imek which is the head of the verb phrase in the source language, and its transformation into an adjectival phrase formed with past participle in the target language; some others, in addition to the reduction of the same verb, are based on translation through adjectives created by other methods of derivation (crazy, impossible, etc.).

Another intervention by Saraç at the modal level is based on the translation of a verb in indicative mode into the source language by converting it into a present participle in the target language. This attempt results in the translator determining one of the two independent sentences as the main sentence, thus converting the other sentence into a subordinate clause. Saraç transforms some of the sentences of the source language into a prepositional group and transfers them to the target language. The modification of the verb type often results in an intervention at the syntactical level.

In conclusion, although a translation strategy must always be defined in the translation process, it is a concept that contains uncertainties. It is clear that the strategies presented under separate headings as a direct or indirect translation strategy cannot be definitively separated from each other, especially when languages with significant structural differences such as Turkish and French are involved.

Although the concept of translation strategy is not sufficient to fully explain the translation process, it is a concept that should be taught to candidate translators in translator training. A novice translator should be able to compare a particular translation product with its source input and determine the type of translator preferences and the reasons for those preferences. 


\section{GíRIŞ}

Çeviri bir edim olarak merkezi eyleyen çevirmenin girdiden hareketle çıktıyı oluşturmaya çalıştığı bir süreci imler. Diğer bir deyişle, girdi, çıktı, merkezi eyleyen ve süreç çeviri ediminin kurucu bileşenleridir. Nitekim Guidère de çeviriyi “bir girdisi, bir çıktısı, bir merkezi eyleyeni bulunan düzenli işlemler dizisi” olarak tanımlar (Guidère, 2016, s. 14). Tanım çerçevesinde bakıldığında, çeviri araştırmaları girdi, çıktı, merkezi eyleyen ve süreçten biri üzerine veya bunların birbirleriyle ilişkileri üzerine de odaklanabilmektedir. Bu çalışmada girdi olarak şiirin çeviriye konu olduğu durumlarda merkezi eyleyen olarak çevirmenin başvurduğu stratejiler araştırılmaktadır. Dolayısıyla, çalışmada girdi (kaynak metin, çıkış metni) ile çıktı (erek metin, varış metni) ilişkisi merkezi eyleyen üzerinden ele alınmakta, böylece süreç hakkında veriler elde edilmeye çalışılmaktadır. Bu amaçla, öncelikle girdi olarak şiir ve şiir çevirisine ilişkin kuramsal yaklaşımlar hakkında kısa bilgiler verilmektedir. Bu doğrultuda çeviri sürecinde başvurulan stratejiler tanımlanmakta, ardından Tahsin Saraç ${ }^{1}$ tarafından Türkçeden Fransızcaya çevrilmiş olan Yunus Emre şiirlerinden birkaçı bu açıdan incelenmektedir. Araştırma ile elde edilen verilerin çevirmen eğitimi sürecinde genç çevirmen adaylarının yararlanacağı temel kaynakların oluşturulmasına katkı sağlayabileceği düşünülmektedir.

\section{KAVRAMSAL ÇERÇEVE}

\subsection{Girdi Türü Olarak Şiir ve Çevrilebilirliği}

Çeviribilim alanyazınında kaynak metin, çıkış metni, çevrilecek metin gibi adlarla da anılan girdi, çıktının varlık nedeni ve onu var eden temel bileşendir. Her tür dilsel üretim ancak çeviri edimine konu edildiğinde çeviribilimin inceleme alanına girebilmektedir. Diğer söylem türleri gibi şiir de çeviriye konu edildiği anda girdi niteliği kazanmaktadır.

Şiir ile çeviri edimi yan yana gelince, akla pek çok soru gelebilmektedir. Bunlardan ilki, şiirin çevrilip çevrilemeyeceği, ikincisi şiiri kimin çevireceği, üçüncüsü de nasıl çevrileceği sorularıdır. Çeviri tarihinde çevrilebilirlik-çevrilemezlik ikiliği şeklinde tanımlanan bu tartışma (Guidère, 2016, s. 24) öncelikle dinsel metinlere özgü bir tartışma olarak ortaya çıkmıştır. İlk bakışta yalnızca dinsel bir tartışmaymış gibi görünse de aslında "kutsal kelamın” bir söylem türü olarak gerektiği gibi aktarılıp aktarılamayacağını da içermektedir. Dolayısıyla, şiirin çevrilip çevrilemeyeceği tartışması ile kutsal metinlerin çevrilip çevrilemeyeceği tartışması bir noktaya kadar aynıdır.

Şiirin çevrilebilirliği konusunu ele alan şair ve çevirmenler çevrilemezlikle ilgili birçok gerekçe sıralarlar, ancak insanlık tarihi boyunca birçok dile çevrilmiş şairler ve şiirler

1 Tahsin Saraç 1 Ocak 1930 Muş doğumlu olup 29 Haziran 1989'da yaşamını yitirmiştir. 1952 yılında Ankara Gazi Eğitim Enstitüsü Fransızca Bölümünü bitirdikten sonra 1953-1954 ve 1957-1959 yıllarında Paris’te bulunan Sorbonne Üniversitesi’nde Fransız Dili ve Edebiyatının yanı sıra sesbilim üzerine öğrenim görmüştür. Bir süre Trabzon Lisesi'nde öğretmen olarak çalıştıktan sonra mezun olduğu okulda önce asistan, daha sonra da öğretim görevlisi olmuştur. Türkçeden Fransızcaya, Fransızcadan da Türkçeye çok sayıda çeviri yapmış olan Tahsin Saraç aynı zamanda şair ve öykü yazarıdır. 
bulunduğunu da belirtmeden edemezler (Paz, 2012, s. 97; Eyuboğlu, 2003, s. 119; Andrei, 2014, s. 149; Newmark, 1998, s. 17). Fransız yazınının büyük şairleri Baudelaire ile Valéry şiir çevirisine ilişkin iki farklı görüşü temsil etmektedir (Efim Etkind'den aktaran Raková, 2016, s. 115). Baudelaire şiirin ancak uyaklı düzyazı ile çevrilebileceğini, diğer bir deyişle biçimsel ve biçemsel özellikleriyle çevrilmesinin mümkün olmadığını savunurken, Valéry ise çevirinin mümkün olduğunu belirtir. Fakat Valéry anlamı çevirmenin yetmeyeceğinin, özgün şiirin bürünbilgisi dâhil biçiminin de aktarılması gerektiğinin altını çizer.

Şiirin çevrilemeyeceği görüşünün dayanaklarından biri çeviri tarihinde bilinen ilk kuramcılardan dilbilimci Georges Mounin (1963, s. 43-47) tarafından Sapir-Worf'un dil içi dünya görüşü ve Humboldt'un dilsel görecelik kavramına dayanılarak açıklanmaktadır. Buna göre, diller düşünceyi ve dış dünyayı farklı biçimde kesitlere ayırdığından, diller arasında sözcük sayısı aynı değildir ve iki dil arasında çeviri ancak belli ölçülerde yapılabilir (1963, p. 42). Özellikle biçimin değil, içeriğin daha önemli olduğu yararcı söylem türlerinde çeviri her zaman mümkündür. Zira bu tür söylemlerde içerik yararına biçimden vazgeçilebilmektedir. Fakat bu, bütün söylem türlerinde her zaman mümkün olamamaktadır. Örneğin şiirde, yazınsal söylemde ve sözcük oyunlarında biçim içerik kadar önemli hâle gelmektedir. Paz bu durumu düz anlatım ile şiir karşıtlığına dayanarak şöyle açıklar: "Düz anlatımda sözcükler birbirlerinin yerine kullanılabilirler”, fakat “(ş)iirin anlamları çok yönlü ve kaypak, sözcükleri ise yalnızca o şiire özgüdür; bunların yerini başka sözcüklerin tutması olanaksızdır” (Paz, 2012, s. 103). Öte yandan Henry (2003, s. 98) de aynı bakış açısını biçim-içerik kuramı çerçevesinde ele almakta, bilimsel ve yararcı metinlerde (gazete haberleri, bilimsel metinler vb.) genel olarak anlamın, özel olarak düzanlamın önemli olması nedeniyle çevrilebilirliğin yükseldiğini göstermektedir. Buna karşılık, içinde şiirin de bulunduğu sözcük oyunları içeren söylemlerde (roman, reklam, şiirsel metinler, sloganlar, sözcük oyunları) ses ve yananlam bütünlügü önemli olduğu için çevrilebilirlik görece düşmektedir. Tekerleme veya benzeri dilsel üretimlerde içerik hiçbir önem taşımamakta, tekerlemenin varlık nedeni bütünüyle sesçil boyutu olmaktadır.

Türk şair ve çevirmenlerden Oktay Rifat ise çevrilebilirlik tartışmasında kimi şiirlerin çevrilebileceği, kimilerininse çevrilemeyeceği görüşünü savunmaktadır. Rifat'a göre, Mallarmé'yi Türkçeye çevirmek olanaksızken, Orhan Veli’yi bütünüyle çevirmek ancak ustalıkla yapılması koşuluyla mümkündür (2003, s. 126). Diğer bir çevirmen Sabahattin Eyuboğlu (2003, s. 118) ise şiir çevirisinin olanaksızlığından yana görüş belirtmektedir. Eyuboğlu'na göre, şiir çevirmek şiirin güzelliğini oluşturan ses, anlam ve çağrışım bütününü bozarak yeniden kurmaya dayandığı için “(b)ir insanı yeniden yaratma”ya benzer.

Türkçeden İngilizceye ve İngilizceden Türkçeye Yunus Emre'ninkiler de dâhil olmak üzere birçok şiir çevirisi gerçekleştirmiş olan Halman kendisiyle yapılan bir söyleşide “(...) Türk şairlerinin eserlerini İngilizce'ye çevirirken ne gördüğü, Türk şiirinin İngilizceye çevrildiğinde zenginleşip zenginleşmediği ve (...) ruhunu biraz da olsa yitirip yitirmediği...” sorulduğunda, yanıtı şiir türüne göre farklı olmuştur. Nitekim Halman'a göre, “(s)erbest nazım tarzında ve Batı şiiri doğrultusunda yazılmışsa” Türk şiirleri İngilizcede zenginleşebilmektedir. Buna 
karşılık biçimsel yönü ağır basan ölçüye dayalı Divan şiirleri İngilizcenin uyak yetersizliği nedeniyle, çoğu zaman çeviride zorlama ve yapay gözükmektedir (Börekçi, 2015).

\section{2. Şiir Çevirisine İlişkin Kuramsal Yaklaşımlar}

Şiir söyleminin çevirisi üzerine görüş belirtmiş olan çeviribilimcilerden biri olan Edmond Cary’ye göre (2012, s. 58) "şiir çevirisi türünün şiir alanından kaynaklanan kendine özgü kuralları bulunur”. Buna göre, “(e)ğer bir şiirin anlamı sözcüğü sözcüğüne veriliyor ya da prozodisi aktarılıyor ama şiirsel değeri başka bir yerde yatıyorsa o zaman kötü çeviri yapılmış olacaktır" (2012, s. 58). Cary çevirmenin birbirinden çok farklı şairlerin şiirsel özünü hissetmenin ve aktarmanın zorluğunu vurguladıktan sonra, çevirmenin, bu işi başarabilmesi için, yazarın duygu durumunu hissetmesi gerektiğini belirtmektedir.

Efim Etkind Un art en crise, essai de poétique de la traduction poétique (1982, s. 18-22) adlı yapıtında Fransa' da şiir çevirisine ilişkin beş yaklaşımdan söz eder: bilgilendirme çevirisi, yorumlama çevirisi, çağrıştırma çevirisi, yaklaştırma çevirisi, yeniden yaratım çevirisi ve öykünme çevirisi (Ayrıca bkz. Andrei, 2014; Rakova, 2016). André Lefevere (1975'ten aktaran Andrei, 2014, s. 153) ise şiirin çevirisi için sesbirimsel, yazınsal, ölçülü, düzyazıl, uyaksız ve uyaklı olmak üzere birçok strateji önerir. Söz konusu stratejileri inceledikten sonra kendisi de biçem çevirisi ve örüntü şiir çevirisi adını verdiği iki strateji daha ekleyen Köksal (2008, s. 74-75)'a göre, şiir çevirisinde “. .. ritmin, sözcük oyunlarının, ölçülerin, ses yinelemelerinin ve tekrarın seçimi önemli rol oynamaktadır” (2008, s. 78). Araştırmacı şiir çevirisinin düz anlatım çevirisine oranla daha sınırlı ve bağlayıcı olduğunun altını çizmekte ve Rosenberg'den hareketle erek metnin okur üzerinde yaratacağı etkiyi ve şairin yaratıcılığının yakalanması gerektiğini vurgulamaktadır (2008, s. 78).

\section{3. Çeviri Stratejisi Kavramı}

Diller arası çeviri sürecinde merkezi eyleyenin dönüştürme işlemlerini nasıl gerçekleştirdiğini açıklarken kullanılan kavram olan strateji yerine alanyazında yöntem terimi de kullanılmaktadır. Bu konuda en yaygın bilinen görüşler olasılıkla Vinay ve Darbelnet (1958, 1995), Newmark (1998) ve Baker (1992)'ın çalışmalarında yer almaktadır. Aynı kavramı ele almakla birlikte üç kuramcı da farklı yaklaşımlarla ve adlarla strateji kavramını açıklamaya çalışmıştır.

Newmark strateji yerine yöntem terimini kullanmakta ve çeviri sürecinde başvurulan yöntemleri sözcüğü sözcüğüne, bire bir, sadık, anlamsal, serbest, deyimsel, iletişimsel çeviri yöntemleri ile uyarlama başlıkları altında sıralamakta ve ayrıntılandırmaktadır (1998, s. 45-48). Fakat araştırmacı yöntemlere ilişkin asıl görüşünü çevirinin başlıca iki amacı olarak belirlediği açıklık ve ekonomi üzerinden açıklar (Newmark, 1988, s. 48). Araştırmacıya göre, anlamsal çeviri iletişimsel çeviriye göre daha ekonomik olma şansına sahiptir. Çünkü genellikle anlamsal bir çeviri yazarın düzeyine göre yapılırken, iletişimsel çeviri okurun düzeyine göre yapılır. Newmark anlamsal çeviri ile iletişimsel çeviri arasındaki diğer farkı metin türleri üzerinden açıklar. Buna göre, anlamsal çeviri "dışavurumsal” metinler için kullanılırken, "bilgilendirici” 
ve "yaptırımcı" metinler için iletişimsel çeviri kullanılır. Ünlü çeviribilimciye göre, anlam çevirisi ile iletişim çevirisi aslında birbirini tamamlayarak bir bütün oluştururlar.

Mona Baker (1992, 2011, s. 23-44) ise çeviri sürecinde iki dil dizgesi arasında eşdeğerlik sağlamak üzere çevirmenin benimsediği yaklaşımları ve yaptığ 1 tercihleri strateji başlığı altında ele almaktadır. Bunu yaparken, çeviri edimine konu olan dilsel birimlerin düzeyini çıkış noktası olarak kabul etmektedir. Diğer bir deyişle, Baker profesyonel çevirmenlerin sözcük, sözcük üstü ve metin düzeyinde karşılaştıkları eşdeğerlik güçlüklerini aşmak üzere yaptığı tercihleri strateji olarak ele almakta ve açıklamaktadır. Baker'a göre, profesyonel çevirmenler sözcük düzeyinde ortaya çıkan eşdeğerlik sağlama güçlüklerinin daha geniş kapsamlı bir sözcükle (İng. superordinate), yansız/duygu yükü az sözcükle, kültürel yerine koyma, açıklamalı ödünçleme, açımlamalı ilişkili sözcükle, açımlamalı ilişkisiz sözcükle çeviri, göz ardı etme ve resimle çeviri stratejilerini kullanmaktadırlar. Sözcük üstü düzeydeki birimlerin (eşdizimli sözcükler, deyimler ve kalıp sözler) eşdeğerliğini sağlamak üzere profesyonel çevirmenlerin başvurduğu stratejiler Baker tarafından a) anlam ve biçim bakımından koşut bir deyimin kullanılması b) anlamsal olarak koşut, fakat biçimsel olarak koşut olmayan bir deyimin kullanılması c) kaynak dil (bundan böyle KD) deyiminin ödünçlenmesi d) açımlama ile çeviri e) deyimin bir bölümünün göz ardı edilmesi f) deyimin tamamının göz ardı edilmesi şeklinde sıralanmaktadır. Sözcük üstü düzeyde eşdeğerlikteki son aşama metinsel eşdeğerliktir. Baker bu düzeyde konu, bilgi yapısı ve bağıntı kavramlarından söz etmektedir. Baker'a göre, profesyonel çevirmenler, konu ve bilgi yapısı düzeyinde eşdeğerliği sağlamak üzere kip, çatı ve eylem değiştirmeye başvururken, bağıntı düzeyinde eşdeğerliği sağlamak üzere eylemcil yapıların adlaştırılması, gönderim öğeleri, yerine koyma öğeleri, eksiltili yapılar, bağlaçlar ve sözcüksel bağdaşıklık düzeyinde kimi müdahaleler yapmaktadırlar.

Çeviribilim alanyazınında çeviri stratejileri konusunda bilinen en yaygın düşünceler yöntem ve teknik adı altında Vinay ve Darbelnet tarafından önerilmiştir (Aktaran Raková 2016, s. 85-92). Kanadalı dilbilimcilere göre, çeviri sürecinde çevirmen biri doğrudan diğeri ise dolaylı olmak üzere başlıca iki ana teknik ve yönteme başvurmaktadır. Doğrudan yöntemler ödünçleme, öykünme, bire bir çeviri iken dolaylı yöntemler ise dönüştürüm, değiştirim, eşdeğerlik ve uyarlama olarak sıralanmaktadır. Dolaylı çeviri yöntemlerinden ilki dönüştürüm “(i)letinin anlamını değiştirmeksizin, söylemin bir parçasını bir başkasıyla değiştirmeye dayanan yöntemdir.” İki dil arasında uygulanabileceği gibi aynı dil içerisinde de uygulanabilir. Sözcük ulamlarının birbirlerine (adın sıfat, sıfatın ad vb.) dönüştürülmesine dayanan yaklaşım iki dil arasındaki ulamlar arasında farklılıklar bulunduğunda zorunlu, benzerlikler bulunduğunda ise seçimliktir. Değiştirim “(b)ire bir çevirinin veya dönüştürümün dilbilgisel olarak doğru, fakat varış dilinin düşünme biçimine aykırı bir sözceyle sonuçlandığının anlaşılması durumunda (...)" başvurulan bir yaklaşımdır. Seçimlik ve zorunlu olmak üzere iki biçimi bulunan değiştirim üretimsel dönüşümlü dilbilgisindeki tanımlandığ1 şekliyle temel yapının dönüştürülmesine (olumlunun olumsuz, edilgenin etken vb. biçiminde değiştirilmesi) dayanmaktadır. Eşdeğeriyle çeviri “(i)ki metnin aynı durumu biçemsel ve yapısal olarak bütünüyle farklı araçlara başvurarak açıkladıklarında” eşdeğeriyle çeviri söz konusudur. Kalıp sözler, atasözleri, adsıl veya sıfatsıl 
bileşikler vb. genellikle eşdeğeriyle çevrilir. Dolaylı yöntemlerin sonuncusu uyarlama Vinay ve Darbelnet tarafından "çevirinin en uç noktası” şeklinde nitelenmektedir. “(...) İletinin gönderme yaptığı durumun varış dilinde var olmadığı durumlarda uygulanmakta olup eşdeğer olduğu değerlendirilen başka bir duruma göre yeniden oluşturulması (...)” söz konusudur. Vinay ve Darbelnet'nin sözünü ettiği yöntemler aslında çevirmen eğitimi amacıyla belirlenmiş yöntemler olup kesin olmayan ve aynı metin içerisinde biri veya birçoğu aynı anda kullanılabilen yöntemlerdir. Birçok açıdan da eleştirilmektedir. Örneğin Ballard, Vinay ve Darbelnet'nin sıraladığ 1 yöntemleri nicelik ve nitelik bakımından çeviri işlemini açıklamak açısından yeterli görmemektedir (2006, 2-6). Araştırmac1, özellikle eşdeğerliği, Jakobson ve Ladmiral'in görüşlerine dayanarak, her tür çeviri girişiminin erişmek istediği son nokta olarak görmekte ve bir strateji olarak değerlendirilemeyeceğini vurgulamaktadır (2006, s. 5).

\subsection{Yunus Emre, Şiiri ve Tahsin Saraç}

Hicri 638-720, miladi 1240-41 ile 1320 yılları arasında yaşamış olan Yunus Emre'nin öne çıkan niteliği onun halk şairi olmasıdır. İkinci niteliği ise şiirlerini Türkçe olarak söylemesidir. Bu Türkçe de arı ve halkın ağzındaki Türkçedir. Günümüzden bakınca elbette eskimiş, günümüze kadar gelememiş kimi sözcük ve kullanımlarla karşılaşmak mümkün olmakla birlikte, Yunus’un şiiri bugün bile büyük ölçüde anlaşılabilir bir dile sahiptir. Yunus'un şiirine ilişkin diğer bir nitelendirme hiç kuşkusuz şiirlerinde yansıttığg insancıl bakış açısıdır. Şiirlerinde dinsel olduğu kadar mistik ve gerçeküstü yönler dikkat çeker.

Araştırmaya konu olan Yunus Emre şiirleri 1973 yılında o zamanki adıyla Turizm ve Tanıtma Bakanlığg tarafından yayımlanmış Yunus Emre Şiirler (Yunus Emré, Poèmes) adlı kitapta yer almaktadır. Şiirler Sevgi, Ölüm, Tanrı'ya Ulaşma, Bilgelik Yolu ve Bilim-GerçekEsenlik izleklerine göre Saraç (1973) tarafından seçilmiş ve çevrilmiştir.

\section{ARAŞTIRMAYA İLIŞKIIN BÍLGILER}

\subsection{Araştırma Geçmişi}

Yunus Emre'yi, onun şiirlerini ve çevirilerini ele alan çok sayıda çalışma bulunmaktadır. Bu çalışmalardan en dikkat çekici olanlardan biri Tuncel (1971) tarafından yapılmış olup elli sayfalık incelemede Yunus Emre'nin Fransızcaya bazıları I. Mélikoff, Yves Régnier, Sabahattin Eyuboğlu ve Burhan Toprak tarafından çevrildiği anlaşılan, bazıları ise açık bir biçimde çevirmeni belirlenemeyen birçok şiiri ve çevirileri hakkında bilgi verilmiştir. Tuncel'in araştırmasında çevirilere yönelik değerlendirmelerin genellikle "aslına uygun", "Fransızcası başarılı", "serbest, Fransızca yönünden sade, yapmacıksız bir dil”, "biçimini bozmıyan², ölçülü, tok bir çeviri” gibi nitelemelerle yapıldığı görülmektedir (Tuncel, 1971, s. 140, 147, 152, 161).

Daha yakın tarihli diğer bir çalışmada, 1949 yılında Yves Régnier tarafından yapılmış olan Yunus Emre şiirlerinin uyarlanmaları Coşkun (2018, s. 54) tarafından incelenmiştir. Coşkun

2 Özgün metindeki yazım bozmıyan şeklinde olduğu için korunarak aktarılmıştır. 
Yves Régnier'in uyarlamalarına ilişkin olarak şiir çevirisi yaparken uyarlama süreçlerini uyguladığı, hedef kültüre anlamsal bir geçiş yaptığı, anlamı koruma gayreti güttüğü, yapısal unsurları pek dikkate almadığı sonucuna varmıştır.

Arıkan ve Temur (2019) tarafından yapılan bir başka çalışmada da Talât Halman'ın Yunus Emre'den İngilizceye yaptığı şiir çevirileri çeviri stratejileri bakımından incelenmiş, çevirilerin Yunus'un anlayışını ne kadar yansıttığı araştırılmıştır. Araştırmacılar farklı şairlerce yapılan aynı şiir çevirilerinin çeviride eşdeğerlik olmayacağı görüşünü desteklediği sonucuna varmışlardır.

\subsection{Yöntem, Veri Toplama, Çözümleme Teknikleri ve Sınırlılıklar}

Çalışmada nitel ve nicel verilerin birlikte kullanıldığı zenginleştirilmiş desen tercih edilmiştir. Geçmişe dönük kaynakların belli soruları yanıtlamak üzere taranmasına dayanan belge incelemesi yöntemi (Gürbüz \& Şahin, 2015) araştırmada kullanılan temel yöntemdir. Yöntem doğrultusunda, Tahsin Saraç'ın 1973 yılında, o zamanki adıyla Turizm ve Tanıtma Bakanlığı tarafından Yunus Emre Poèmes adıyla yayımlanan ve Yunus Emre'nin şiir çevirilerini içeren kitabında yer alan 10 şiiri seçilmiştir: (1) Şöyle Garip Bencileyin, (2) Gel Gör Beni Aşk Neyledi, (3) Bana Seni Gerek Seni, (4) Tout est dans l'être humain, (5) İlim İlim Bilmektir, (6) Taştın Yine Deli Gönül, (7) Sevelim Sevilelim, (8) Işitin Ey Yarenler, (9) Benim Bunda Kararım Yok, (10) Hak Bir Gönül Verdi Bana. Şiirler seçilirken elimizde bulunan divanlarda (Tatc1, 2012; Yazarsız, ybm.) yer alıyor olmalarına ve çeviri şiirlere kaynaklık etmiş olma olasılıklarına dayanılmıştır. Çünkü Saraç kitaba yazdığı önsözde şiirleri hangi kaynaktan seçtiği konusunda bilgi vermemiştir.

Seçilen şiirler bilgisayarda oluşturulan bir Excel tablosuna girilmiştir. Tabloda şiir adı, Türkçesi, Fransızcası, eksiltme, artırma, müdahale, düzey ve strateji başlıklarına yer verilmiştir. Daha sonra Türkçe ve Fransızca çeviriler karşılaştırılarak kaynak metinde var olan, ancak erek metinde var olmayan öğeler söz konusu olduğunda, eksiltme sütununa; kaynak metinde var olmadığı hâlde erek metinde var olan öğeler belirlendiğinde, artırma sütununa işlenmiştir. Müdahale başlıklı sütununda çevirmenin yaptığı müdahale betimlenmiş, düzey sütununda ise bu müdahalenin sözlüksel, sözdizimsel ve dilbilgisel düzeylerden hangisinde yer aldı̆̆ not edilmiştir. Yöntem sütununda ise çevirmen tarafından benimsenen yaklaşımın dolaylı mı yoksa bire bir mi olduğu belirtilmiştir. Çeviri eleştirisi amacı taşımayan çalışma Yunus Emre'nin Tahsin Saraç tarafından çevirisi yapılan ve yukarıda sıralanan şiirleri ile sınırlı olup tümce düzeyinde hangi müdahaleler yapıldı̆̆ını belirlemek üzere gerçekleştirilmiştir. Ayrıca çevirmen tarafından strateji tercihleri yalnızca sözdizimsel düzeyle sınırlandırılmıştır. Diğer bir deyişle, çevirmenin ED metninde tümce düzeyini etkileyen girişimleri dikkate alınmıştır.

Girdiye ilişkin veriler incelendiğinde, dize sayısı bakımından iki farklı görünüm dikkat çekmektedir: dört dizeli ve iki dizeli şiirler. Fakat dize sayısı araştırma sorumuz açısından yeterli derecede açıklayıcı olmayacağından dizeleri oluşturan tümce sayıları da incelenmiş ve on iki farklı görünüm belirlenmiştir. Araştırmanın sınırlanma zorunluluğu nedeniyle bunlardan yedisi incelenmiştir. 


\subsection{Verilerin Çözümlenmesi}

\subsubsection{Dört Dize Bir Tümce}

Bu görünümlerden ilki dört dizeye karş1lık yalnızca bir tümcenin bulunduğu 4, 9 ve 6 numaralı şiirlerdeki öneklerdir. Bu şekildeki örnek sayısı 8'dir:

[1]
a) gice ile gündüzi
b) gökde yidi yılduzı
c) levhde yazılan sözi
d) cümle vücudda bulduk

Örneklerin 6's1 4 numaralı şiirde yer almakta olup dörtlüklerden birine (7'nci) erek dilde (bundan böyle ED) rastlanmamıştır. Dizeleri oluşturan tümceler incelendiğinde, birinci, ikinci ve üçüncü dizelerde dörtlük sonunda yer alan "bulduk" eyleminin düz tümleçlerinin sıralandığ 1 görülmektedir. Bu düz tümleçlerin her birinin belirtili ad öbeği olduğu ve birçoğunun Gösteren $+S \ddot{O}+A \ddot{O}+B e l D u r^{3}$ dizilişine sahip olduğu anlaşılmaktadır. Son dize bu açıdan farklı olup önceki adların yerine geçen bir adıl (cümle), ad öbeği ve eylem öbeği içermektedir: AdlÖ + $A \ddot{O}+B u l D u r+E \ddot{O}$. Fakat SÖ konumundaki sözcüklerin kimi zaman sözcük türü bakımından sıfat (yidi, yitmiş bin vb.) kimi zamansa sıfat işlevinde kullanılan eylemcil birimler (çizginen, yazılan, Musa'nun agdugı, İsrâfil çalduği vb.) ile durum eki (-dA $\left.{ }^{4}\right)$ ile -ki biçimbiriminin birleşiminden oluşan koşaçsı birim (-dAki) (bunlardagı beyanı) olduğu anlaşılmaktadır.

Saraç'ın çeviri yaklaşımı incelendiğinde, öncelikle KD'deki dört dizeyi ED'de tüm kitap boyunca iki dizeye indirdiği görülmektedir. Dize sayısında KD’ye göre farklı tutum benimsemiş olmasına karşın, çevirmen tümce sayısı bakımından kaynak metne bağlı kalmayı tercih etmiştir:

[2]
a) Bu çizginen gökleri
b) Tahte's-serâ yirleri
$a b$ ') Les cieux qui tournent sans cesse, et tous ces mondes souterrains
c) Yitmiş bin hicâbları
d) Cümle vücudda bulduk
cd') Et les soixante-dix mille voiles, tout est dans l'être humain.

Fakat Saraç KD metninden farklı olarak Özne + Tümleç + Eylem dizilişini ve geçişli bir eylemi değil, Özne + Koşaç + Yer Tümleci dizilişini tercih etmiştir. Diğer bir deyişle, sözdizimsel yapıyı bütünüyle değiştirmiştir. Bunu yaparken, özgün metindeki tümleçleri erek metindeki özne hâline getirmiştir. Saraç dörtlü dizedeki uyakların önemli bir bölümünden vazgeçmiş olmasına rağmen, ilk iki dizede souterrains ve humain sözcükleri arasında uyak oluşturmayı başarmıştır. Ancak, aynı durum diğer dizelerde söz konusu olmamıştır.

3 SÖ: Sıfat öbeği; AÖ: Ad öbeği; BelDur: Belirtme Durumu; EÖ: Eylem öbeği.

4 -dA: -da, -de, -ta, -te. 
İlgili dizelerde yer alan ad öbeklerinin ilgi adılı (-An, -dIk) ile genişlemiş olanlarının bazıları -(y)An karşılığında qui, -dIk karşılığında où kullanılarak bire bir çevrilmişken,

[3] bu çizginen gökleri - les cieux qui tournent sans cesse

[4] Musa 'nun agduğı Tûr' ' - Le Sinaï où monta Moïse

bazıları eksiltilerek çevrilmiştir. Levhde yazılan sözi öbeğindeki yazılan birimi olağan koşullarda qui est écrit biçiminde çevrilebilecekken bu yol tercih edilmemiş, ayraç içerisinde eklediğimiz bölüm eksiltilmiştir:

\section{[5] Levhde yazlan sözi - la Parole (qui est écrite ${ }^{5}$ ) dans Tables de la Loi}

Benzer yapıda olmakla birlikte -dAki biçimbirimi ile genişlemiş ad öbeği yukarıdakinin aksine Fransızcaya genişletilerek çevrilmiştir. Bu yapılırken KD'deki koşaçlı yapı ED'de geçişli eylemli bir yapıya dönüştürülmüştür. Diğer bir deyişle, dize bire bir çevrilmiş olsaydı les révélations qui sont (se trouvent) dans celles-ci denmesi beklenirken bunların içerdikleri beyanlar şeklinde çevrildiği görülmektedir. Altı çizilmesi gereken bir tercih de ED'de tekil olarak yer almakta olan beyan sözcüğünün ED'de çoğul (les révélations) olarak çevrilmiş olmasıdır:

[6] Bunlardagı beyanı - les révélations qu’ils comportent

İlgi adılıyla genişlemiş adlardan biri olan İstrafil'(in) çalduği Sûri öbeğinin Saraç tarafindan eylem çatısı değiştirilerek çevrildiği görülmektedir. Nitekim bire bir çevirisi trompette qu 'Israfil avait entonnée yerine edilgen çatıda aktarılmıştır:

\section{[7] İsrafil çalduği Sûri - Trompette entonnée par İsrafil}

Diğer ad öbekleri de birkaç farklı görünüm sergilemektedir. Birinci gruptakiler niteleme sıfatı içermeyen yalın ardışık iki ad olarak yer alırken,

[8] tagları denizleri - les montagnes et les mers

ikincisi niteleme veya niceleme sıfatı içermektedir. Saraç bunları genellikle bire bir çeviri yoluyla aktarmaya çalışırken erek metinde et'nin eklenmiş olması dikkat çekicidir. Eklentinin dışında, yohsa'nın da eksiltildği görülmektedir:

[9] Tahte's-serâ yirleri - et tous ces mondes

[10] yitmiş bin hicâblart - et les soixante-dix mille voiles

[11] yohsa Beytü'l-Ma'mûr' l - la Kabba des anges dans le ciel

Ad öbeklerinden bir bölümü ile bağlacı ile bağlı adlar olup Saraç bunları et bağlacı ile çevirmiştir. Nitekim Türkçede ile bağlacının işlevlerinden biri de ve bağlacı ile aynıdır. Bu anlamdaki farklı tutum Zebûr'ıla Furkân' $\imath$ öbeğinde gözlemlenmektedir, çünkü Saraç burada et yerine ainsi que bağlacını tercih etmiştir:

5 Tarafımızca eklenmiştir. 
[12] uçmă̆ıla Tamu'yı - le paradis et l'enfer

[13] gece ile gündüzi - le jour et la nuit

[14] Tevrât'ila Incil'i - l'Evangile ainsi que la Bible,

[15] Zebûr'ıla Furkân'ı - le Coran ainsi que les Psaumes

İlgili bölümde yer alan ad öbekleri arasında çok sayıda özel ya da kültürel nitelikli ad (Zebur, Furkan, Kur'an, Musa, Sina, Levh) yer almakta olup Saraç bunları ED özelliklerine uygun hâle getirerek çevirmeyi tercih etmiştir.

Aynı öbekte yer alan, ancak içerdiği yapılar bakımından farklılık sergileyen bir örnek 6 numaralı şiirde yer almaktadır. Dörtlükteki ilk üç dize son dizedeki eylemin (ağlar mısın) öznesi konumundadır. İlki -An ilgi adılı, ikincisi -Ip ulacı ile ana tümceye bağlı iki yan tümce söz konusu olup birleşik tümce yapısındadır. Dize ayrıca "salkım salkım olmak" ve "yaşın yaşın ağlamak” gibi Türkçede sıkça kullanılan ikilemeye dayalı belirteç öbekleri içermektedir.

Saraç çeviri sırasında dört dizeyi iki dizeye indirme yaklaşımını benimserken, KD’deki tümce yapısını korumuştur:

[16]
a) Karlı dağların başında
b) Salkım salkım olan bulut
ab') Nuage en grappes sur le sommet des montagnes neigeuses,
c) Saçın çözüp benim için
d) Yaşın yaşın ağlar mısın
cd') Défaisant tes cheveux, pleureras-tu pour moi en secret?

Bunu yaparken kimi öbekleri (karlı dağların başında) olduğu gibi çevirmiş, kimilerini ise eksiltmiştir. Nitekim ad yinelemesi ile elde edilen salkım salkım ikilemesini, yapısal zorunluluk nedeniyle, en grappes şeklindeki ilgeç öbeğine dönüştürmüş, fakat olan birimini eksiltmiştir. Gerçekte aynı birim (olan) Türkçede de zorunlu bir yapı olmayıp eksiltilebilmektedir:

[17] karlı dağların başında - sur le sommet des montagnes neigeuses

[18] salkım salkım olan bulut - nuage en grappes

Üçüncü dizede yer alan -Ip ulacı ile ana tümceye bağlı yan tümce Fransızcada benzer bir kipsel birim olan participe présent (défaisant) ile verilmiştir. Saç sözcügüünün KD'de tekil, ED'de çoğul olması dilsel yapıya bağlı zorunlu bir uygulamadır. Öte yandan yaşın yaşıın ikilemesi de en secret şeklinde ilgeç öbeğine dönüştürülerek çevrilmektedir. Aynı dörtlükte not edilmesi gereken en önemli çevirmen tercihlerinden biri KD'de bildirme kipi geniş zamanda çekilmiş olan ana tümce eyleminin (ağlar mısın) gelecek zamanda çevrilmiş olmasıdır:

[19] Saçın çözüp - défaisant tes cheveux

[20] Benim için yaşın yaşın ağlar mısın? - pleureras-tu pour moi en secret? 


\subsubsection{Dört Dize İki Tümce}

Dört dizede iki tümcenin yer aldığı tek örnek 6 numaralı şiirde yer alan aşağıdaki dörtlüktür. KD metninde ilk iki dize son dizedeki tümcenin öznesi olarak genişlemiş bir ad öbeğidir. Genişleme karlı dă̆ ad öbeğine - (y)An ilgi adılı ile yan tümce eklenmesi yoluyla sağlanırken, en son dizede aynı ada gönderme yapan sen adılı ve yüklem (bağlar mısın?) yer almaktadır. Bunların arasına ise bağımsız bir tümce girmektedir. Saraç’ın önceki örneklerde olduğu gibi -(y)An ilgi adılı için bire bir karşılığı qui ilgi adılını tercih ettiği, dolayısıyla bire bir sayılabilecek bir yaklaşımla çevirmeyi tercih ettiği söylenebilmekle birlikte tümce başında yer alan et toi bir eklenti olarak bu düşünceyi boşa çıkarmaktadır. Nitekim arkuru inmek deyimini daraltarak couper eylemi ile sunması, harami gibi ilgeç öbeğinin tekil adı haramiyi ED'de çoğula dönüştürerek sunması da bire bir değil, dolaylı bir çevirinin söz konusu olduğu görüşünü güçlendirmektedir. Buna ek olarak geniş zamanda çekilmiş olan bağlamak eyleminin yakın gelecek zamana dönüştürülerek çevrilmesi bu görüşü güçlendiren diğer bir tercihtir. Kaldı ki aynı dizede yolunu bağlamak deyim öbeğinin barrer la route à quelqu'un şeklinde Fransızcaya özgü bir adıl kullanım biçimi ile çevrilmesi de dilsel farklılıklardan doğan bir zorunlu dönüştürüm örneği olarak not edilmelidir:

[21]
a) Harami gibi yolumu
b) Arkuru inen karlı dă
ab') Et toi, montagne neigeuse qui coupe le chemin comme des brigands

Dörtlüğün son iki dizesinde ayrı düşmek eylemcil deyimi koşaçlı bir yapı olarak être loin şeklinde çevrilmiş, déjà eklenti olarak yer alırken, yârim ad öbeğindeki iyelik ekinin (-im) eksiltilmiş olması dikkat çekmektedir:

[21]

c) Ben yarimden ayrı düştüm

d) Sen yolumu bağlar mısın?

cd') Je suis déjà loin de l'Aimé, vas-tu toi aussi me barrer la route?

\subsubsection{Dört Dize Üç Tümce}

İkinci görünüm türü dört dizeye karşıl1k üç tümcenin yer aldığ örneklerdir. 3, 4, 5 ve 6 numaralı şiirlerde gözlemlenen bu görünüme sahip örnek sayısı 8 ' dir. Bunlar belirlenirken ne ... ne ... bağlacı ile bağlı birleşik tümce olarak kabul edilmesine rağmen bunlar iki ayrı tümce olarak değerlendirilmiştir. Çünkü her ikisi de birbirine göre ana veya yan tümce olarak kabul edilemeyen iki tümce söz konusudur:

[22]
a) Ne varlığa sevinürem
b) Ne yokluğa yirinürem 
ab') Je ne me réjouis de fortune, ni ne me plains d'indigence

c) 'Işkunıla avınuram

d) Bana seni gerek seni

cd') Je me console de ton amour; c'est toi, toi qu'il me faut.

Bu tür dörtlüklerde her bir dize bir tümceden oluşabildiği gibi tümcenin bir bölümü ile diğer bölümü ardışık iki dizede yer alabilmektedir. Bunlardan bir bölümü de ardı ardına iki dizede yer alan bağımsız tümceden sonra son iki dizenin bir yarısının koşul tümcesi, diğerininse sonuç tümcesi olduğu birleşik tümcelerdir.

Saraç bunların çevirisinde farklı yaklaşımlar izlemiştir. Bu yaklaşımlardan ilki dize sayısını dörtten ikiye düşürmeye dayanmaktadır. İkinci yaklaşım ise tümce sayısının kimi zaman artması kimi zamansa azalmasına dayanmaktadır. Aşağıdaki örnekte dört dizede üç tümce şeklindeki KD girdisi iki dizede iki tümce şeklinde dönüştürülerek aktarılmıştır. Bu tümcelerden ilki koşaçlı tümce eylemi imek'in (üçüncü tekil kişi) Fransızcadaki eşdeğeri attributif eylem se trouver ile çevrilmesine dayanmaktadır. Bu yönüyle bire bir çeviri örneği olarak kabul edilebilir. Öte yandan son iki dizede yer alan bağımsız iki tümce mais bağlacının eklenmesi ile tek tümceye dönüştürülerek çevrilmiştir. Son dizedeki tümcenin yüklem konumunda yer alan mastar ve koşaç yapısının bildirme kipine dönüştürülmesi, hoca seslenme bildirimi ile ce que belgisiz adıllarının eklenmesi not edilmelidir. Bu eklentiler buradaki yaklaşımın dönüştürüm örneği olarak not edilebileceğini düşündürmektedir:

[23]
a) Dört kitabın manası
b) Bellidir bir elif'de
$a b$ ') Et le sens des quatre Livres se trouve inclus dans un seul alpha
c) Sen elifi bilmezsin
d) $\mathrm{Bu}$ nice okumaktır
cd') Tu parles d'un seul alpha, hodja, mais sais-tu ce qu'il signifie?

Saraç'ın başvurduğu ikinci yaklaşım ise KD'de üç olan tümce sayısını altıya çıkarmak olmuştur. Çevirmen bunu yaparken, ilk iki dizede yinelenen emir kipi ikinci tekil kişide çekilmiş deme eyleminden birini eksiltmiştir. Son iki dizede yer alan koşul tümcesini ise ikiye ayırmıştır. Bu tercih nedeniyle bildirme kipi emir kipine dönüştürülmüş, eylem öbeğindeki mastar ve koşaç da bildirme kipi gelecek zamana dönüştürülmüştür. Her iki tümce arasına da sinon bağlaç olarak eklenmiştir:

[24]
a) Okudum bildim deme
b) Çok tâat kıldım deme
ab') Ne dis pas: j'ai étudié, j'ai appris et j'ai fait des prières
c) Eri Hak bilmez isen
d) Abes yere yelmektir
cd') Considère l'homme comme Vérité, sinon tes efforts seront vains. 
Bu öbekte yer alan ve en sıklıkla gözlemlenen durum KD’deki üç tümcenin aynı şekilde tümce olarak çevrilmesidir. Bu türden yedi örnek belirlenmiştir. Bu örneklerde tümce sayısı korunmakla birlikte yapısal olarak önemli müdahaleler gözlemlenmiştir. Bunlardan biri "Gerekse var bin hacca” şeklindeki koşul tümcesinin koşul bölümünün eksiltilmesi, emir kipinde çekilmiş var bin hacca bölümünün de gelecek zamanda ifade edilmesidir:

[25]
a) Yunus Emre der hoca
b) Gerekse var bin hacca
ab') Yunus dit: hodja, en vain iras-tu en pélerinage

Bu müdahalenin bir benzeri aynı dörtlüğün son iki dizesinde de gözlemlenmektedir. KD'de yüklem konumunda mastar ve koşaç bulunan bir tümce ED'ye kişisiz eylem valoir' 'n bildirme kipi şimdiki zaman çekimi ile aktarılmıştır. Bu sırada essayer eylemi eklenti olarak ED tümcesinde yer almıştır. Söz konusu örnek eyice'nin bire bir karşılığı olarak kabul edilebilecek olan Il vaut mieux + mastar yapısı nedeniyle bire bir çeviri örneği olarak değerlendirilebilirmiş gibi görünse de koşaçlı yapının geçişli bir eyleme dönüştürülmesi nedeniyle dönüştürüm örneği olarak değerlendirilmektedir:

[25]

c) Hepisinden eyice

d) Bir gönüle girmektir

cd') Il vaut mieux essayer de pénétrer dans un coeur

$\mathrm{Bu}$ öbekte yer alan örneklerden yavu kıldım ben yoldaşı şeklindeki yalın tümce birini bir şey kılmak dizilişinde geçişli bir eyleme sahip olup Fransızcada rendre qqch/qqn qqch dizilişinde değil, tek tümleçli, geçişli bir eyleme dönüştürülmüştür. Dolayısıyla, yavu eksiltilmiş görünmekle birlikte aslında perdre (kaybetmek) eylemiyle çevrilmiştir. Fakat tümce yapısı belirgin bir dönüşüme uğratılmıştır. Aynı tümcenin devamındaki dizede onulmaz eylemi KD'de edilgen bir yapıda olup ED’ye koşaç (être) olarak aktarılmıştır. Bu yönüyle eylemin sıfata dönüştürülmesine dayanan dönüştürüm örneği olarak not edilebilir:

[26]
a) Yavu kıldım ben yoldaşı
b) Onulmaz bağrımın başı
ab') J'ai perdu mon compagnon, ma blessure est inguérissable

Dörtlüğün devamındaki gözlerimin kanlı yaşı ad öbeği pauvres sıfatı eklenmiş olsa da bire bir çevrilmiş sayılabilir. Buna karşılık devamındaki dizede var olan ırmak olup çağlar misın şeklindeki tümcenin ırmak olmak koşaçlı yapısı ilgeç öbeğine (comme fleuves), geniş zaman ise yakın gelecek zamana dönüştürülerek çevrilmiştir. Kaynak metindeki tümcede yer alan tekil kanlı yaş ad öbeğinin, ED'de çoğula dönüştürülerek çevrilmesine bağlı olarak sen kişisinin siz kişisine dönüştürülmesi adıl düzeyindeki dönüşümlere örnek olarak not edilmelidir: 
[26]

c) Gözlerimin kanlı yaşı

d) Irmak olup çağlar misın?

cd') Larmes de sang de mes pauvres yeux, allez-vous ruisseler comme fleuves?

Veri tabanımızdaki 6 numaralı şiirde yer alan ve dört dizenin üç tümce biçiminde çevrildiği örneklerden aşağıdaki koşaçlı yapı ad + olmak'ın eksiltilerek sunulmasına dayanan bir müdahale içermektedir. Toprak sözcügünün poussière ile karşılandığı ED dizesinde ayrıca KD tümcesinde üst tümce ile alt tümce arasında örtük olarak sunulan karşıtlık or'un eklenmesi ile belirtikleştirilmiştir. Bu belirtikleştirme ayrıca $m$ 'en adıllarının eklenmesi ile pekiştirilmektedir:

[27]
a) Ben toprak oldum yoluna
b) Sen aşuru gözetirsin
ab') Me voilà poussière dans ta voie or tu m'en demandes davantage encore

Dörtlüğün son iki dizesindeki - (y)An ilgi adılıyla bağlı yan tümcenin genişlettiği şu karşımda gögüus geren taş bă̆ırlı dă̆lar ad öbeği sözdizimsel yapı olarak bire bir çevrilmiştir. Fakat birçok farklı nedenden dolayı bu görüş geçersiz hâle gelmektedir. Bu nedenlerden ilki ana tümce eyleminin zamanının kaynak metinde şimdiki zaman, erek metinde ise koşul kipi ( $F r$. conditionnel présent) olarak tercih edilmiş olmasıdır. İkinci nedense karşı ve gögüus germek sözcüklerinin farklı tercihlerle çevrilmesidir. Karşımda belirtecinin devant moi ilgeç öbeği ile göğüs germek deyiminin ise se hisser comme des murailles şeklinde genişletilerek sunulması belirtikleştirme kaygısıyla yapıldığı anlaşılan girişimlerdir:

[27]
c) Şu karşımda göğüs geren
d) Taş bağırlı dağlar mısın?
cd') Serais-Tu' ces montagnes qui se hissent comme des murailles devant moi?

Veri tabanımızda dokuz numara ile kayıtlı bulunan şiirin çevirisinde Saraç'ın başvurduğu birkaç farklı yaklaşım gözlenmektedir. Bunlardan ilki, kaynak metinde yer almayan bir yinelemedir. Nitekim, işitin ey yarenler şeklindeki çağrı, eylem yinelenerek verilmiştir: entendez, amis, entendez. Buna karşılık çağrı ünlemi ey erek metinde yer almamıştır. Dörtlüğün ikinci dizesinde ise yukarıda da örneklerine rastladığımız eylemin sıfata dönüştürülmesine dayanan bir yaklaşım benimsenmiştir. Benzemek eylemi semblable sıfatıyla çevrilmiş, tümce yapısı geçişli bir eylemin koşaçlı bir eyleme dönüştürülmesi sonucunda üye yapısı bakımından değil, ama tümce türü bakımından değişikliğe uğratılmıştır. Çünkü bu yolla eylem tümcesinin ad tümcesine (koşaçlı eylem kümesi) dönüştürülmesi söz konusudur:

6 Çevirmen kimi durumlarda adılları büyük harfle yazmayı tercih etmiştir. 
[28]
a) İşitin ey yarenler
b) aşk bir güneşe benzer
ab') Entendez, amis, entendez, l'amour est semblable au soleil

Dörtlüğün son iki dizesinde ise sahiplik belirtme değeriyle kullanılan olmak eylemi ile -(y)An ilgi adılı yoluyla genişlemiş özne kişi eksiltilmiş, onun yerine coeur (kalp) sözcüğü kullanılmıştır. Diğer bir deyişle bütün (kişi) yerine (coeur) parça konularak çevrilmiştir. Aynı şekilde eylemin sıfat niteliğinde kullanımını sağlayan olmayan ifadesi Fransızcada belli bir şeyin eksikliğini ifade eden priver eyleminin sıfat değerli biçimi olan participe passé (être privé de qqch) ile karşılanmış, eylem bir anlamda sıfata dönüştürülmüş̧ür. Önceki dizede aynı eylemle ifade edilen düşünce (benzer) semblable sıfatı ile çevrilmişken, bu dizede ise diğer eşanlamlı sıfat olan pareil ile karşılanmıştır. Bu noktada Saraç'ın Fransızcada da devrik bir yapıyı tercih ettiğinin altı çizilmelidir. Bu yapılırken temel amaç önceki dizenin sonundaki "soleil" ve bu dizenin sonundaki "pareil" sözcükleri arasında uyak oluşturma beklentisidir:
[28]
c) Aş̧ı olmayan kişi
d) misali taşa benzer
cd') Un coeur privé d'amour, à la pierre est pareil

Sekiz numaralı şiirin üç numaralı dörtlüğünde biri basit, ikisi birleşik olmak üzere üç tümce yer almaktadır. Tümcelerden ilki birinci dizede yer alan basit koşaç tümcesidir. İkinci tümce yan tümcenin (aşılar bilir) ana tümceye göre (neliğim) düz tümleç konumunda olduğu birleşik tümcedir. Üçüncüsü bir bölümü üçüncü dizede bulunan ve eski dilde -(y)Ip ulacı ile dördüncü dizedeki ana tümceye bağlanan birleşik tümcedir. Dördüncü dizedeki ana tümce tümleç konumunda mastar eylem içermektedir. Saraç ilk iki dizenin çevirisinde olasılıkla ED'de de uyak oluşturma kaygısıyla birinci ve ikinci dizelerin yerini değiştirmiştir. Dolayısıyla, aşıklar bilir neliğim şeklindeki tümceyi bire bir çeviri yaklaşımıyla aktarmıştır. Bunun sonucunda Türkçe metinde görünür olmayan bağlaç görevindeki öğenin (-dIk) ED'deki karşıllğı que dilsel zorunluluk nedeniyle görünür hâle gelmiştir. Birinci dizedeki koşaç tümcesi de ED'de ikinci konumda ve büyük oranda bire bir çevrilmiş görünmekle birlikte, Fransızcadaki tümce belirgin bir eksiltili yapıdır. Türkçede -imek eylemi üçüncü tekil kişinin sıfır biçim birimle karşılanabiliyor olması nedeniyle KD'deki tümcenin eksiltili olup olmadığını söylemek mümkün olmadığından, çeviri yaklaşımının bire bir olup olmadığı da söylenememektedir:

[29]
a) Dost esrügü deliliğim
b) Aşıklar bilir neliğim
ab') Amoureux savent bien que je suis; ma folie, à cause de l'Aimé

Üçüncü ve dördüncü dizeye dağılmış olan üçüncü tümcenin üçüncü dizedeki ilk bölümü participe présent ile çevrilirken, çeviri yaklaşımı bire bir olarak kabul edilebilir. Nitekim Fransızcadaki söz konusu dilsel yapı Türkçedeki-(y)Ip ulacının olası karşılıklarından biridir. 
Öte yandan dört numaralı dizedeki tümcenin çevirisinde Saraç önemli sözdizimsel girişimlerde bulunmuştur. Tümcedeki birlik, gelmek ve yetmek sözcüklerinin hiçbirini eksiltmemiş olmakla birlikte tümce zamanını geçmiş zamandan şimdiki zamana dönüştürmüştür. Ayrıca tümceyi me adılı ile voilà belirtecinin birlikte kullanımına dayalı eksiltili bir yapıya dönüştürmüştür:

[29]
c) Desgürüben ikiliğim
d) Birlige yetmege geldim
cd') Refusant toute dualité, me voilà qui viens atteindre l'Unité

\subsubsection{Dört Dize Dört Tümce}

Dört dizede dört tümcenin yer aldığg ve 15 örnekle en fazla sayıda örneğin gözlemlendiği görünüm türüne 3, 4, 5, 6, 7, 8 ve 9'uncu şiirlerde rastlanmıştır. Bunun en tipik örneği aşağıdaki dörtlüktür:

[30]
a) Taştın yine deli gönül
b) Sular gibi çağlar mısın
ab) Tu débordes encore, coeur fou, vas-tu murmurer comme les eaux?
c) Aktın yine kanlı yaşım
d) Yollarımı bağlar misın
cd) Et vous mes larmes de sang qui coulez, allez-vous me barrer le chemin?

Saraç bu görünüme sahip şiirlerin çevirisinde de aynı yolu izlemiş ve dize sayısını ikiye düşürmüştür. Bununla birlikte, tümce sayılarında farklı tercihleri olmuştur. Bu tercihlerden ilki dört tümcenin dört tümce olarak çevrilmesidir. Tümce sayısının korunmuş olması bire bir çevrildiği anlamına gelmemektedir. Nitekim üçüncü dizede yer alan birleşik ad tümcesi Ne gördüysen kamu Hak, yine yapısal olarak où ilgi adılıyla bağlı birleşik tümce şeklinde çevrilirken tümcenin önvarsayımı veya sezdirimi çeviri yaklaşımı olarak kullanılmıştır. Aynı yaklaşım son dizede de kullanılmış olup yukarıda uygulanan işlem betimlenmiştir:

[31]
a) Yûnus'un sözleri Hak
b) Cümle didügi saddâk
ab') Les mots de Yunus sont vrais; quant à nous, nous le confirmons
c) Ne gördüysen kamu Hak
d) Cümle vücudda bulduk
cd') Dieu est là où on le veut; tout est dans l'être humain.

Dört dizenin dört tümce içerdiği ve Saraç'ın da dört tümce şeklinde çevirdiği, fakat yine de bire bir çeviri yaklaşımını benimsemediği diğer bir örnek 7 numaralı şiirin 3'üncü dörtlügüünde bulunmaktadır. Dörtlükteki ilk üç dize yükleminde koşaç bulunan ad tümceleri iken dördüncü 
dize özne konumunda -(y)An ilgi adılı ile oluşturulmuş belgisiz adıl (hiç giden) bulunan eylem tümcesidir. Saraç ilk dizede koşaçlı yapıları Fransızca eşdeğerleri être eylemi ile çevirirken yavlakı eksiltmiş; bu eksiltmeyi sonraki tümcenin eylemine de uygulamıştır:

[32]
a) Ahret yavlak irakdır
b) Doğruluk key yarakdır
ab') L'au-delà est lointain; la droiture, indispensable

Dörtlüğün son iki dizesinden ilki bire bir çevrilirken, ikincisi açık bir belirtikleştirme örneği olarak not edilmelidir. Çünkü hiç giden geri gelmez şeklindeki tümcenin önvarsayımı veya sezdirimi çeviri yaklaşımı olarak benimsenirken, en adılı da önceki tümceye gönderme yapıldığını açık hâle getirmek üzere eklenmiştir:

[32]
c) Ayrılık sarp firakdır
d) Hiç giden geri gelmez
cd') Séparation est grande douleur; guérison en est impensable.

Aynı şiirin altıncı dörtlüğüne ilişkin çeviride Saraç koşul yan tümcelerini ayrı ayrı çevirmeyi tercih etmiştir. Devamındaki gereklik tümcesi Sana dirlik gerek sözdizimsel olarak kendisiyle hiç ilişkisi olmayan kişisiz bir tümceye dönüştürülmüştür. Bu tümceyi izleyen dizedeki tümce de sözdizimsel olarak önemli değişikliklere uğratılmış KD’nin dolaylı tümleci kimseye ED tümcesinin öznesi konumuna getirilmiştir. KD’deki geçişsiz eylem kalmak ise bir sıfat (éternel) ile karşılanmıştır. Tümcenin öznesi bunda da ED’de belirteç olarak çevrilmiştir:

[33]
a) Yûnus sözün anlarsan
b) Mânâsını dinlersen
ab') Yunus, tu entends parole; tu pénètres dans le vrai sens, toi
c) Sana iyi dirlik gerek
d) Bunda kimseye kalmaz.
cd') Il faut vivre en bonne intelligence, personne n'est éternel ici-bas

Saraç 8 numaralı şiirde de tümce sayısını korumakta, ancak tümce yapısına ilişkin girişimlerde bulunmaktadır. Bu doğrultuda, şiirin ikinci dörtlüğünün ilk dizesinde $a d+i c ̧ i n$ dizilişine sahip ilgeç öbeğindeki için ilgecini eksiltmekte, öbekteki dâv’i (kavga) adının yerine ise mastar eylem ve tümlecini (susciter des conflits) koymaktadır. Çevirmen ayrıca sonraki dizede eylem konumunda koşaç bulunan benim işim sevi için tümcesinin özne konumunu belgisiz adıl ve geçişli eylem ile yüklem konumunu ise koşaç (Fr. verbe attributif “être”) ile çevirmektedir: 
[34]

a) Ben gelmedim dâv'i için

b) Benim işim sevi için

ab') Je ne suis pas venu susciter des conflits; ce qui m'intéresse c'est l'amour

Dörtlüğün son iki dizesinde eylem kümesinde koşaç bulunan bir ad öbeği (gönüllerdir) ilgeç öbeğine dönüştürülerek (dans les coeurs) çevrilmektedir. Son dizede ise KD'de yinelenen ad ED'de yerine adıl konarak çevrilmiş; KD tümcesinin yüklem konumundaki gelmek eylemi koşaca dönüştürülerek çevrilmiştir.

[34]

c) Dostun evi gönüllerdir

d) Gönüller yapmağa geldim

cd') Demeure de l'Ami est dans les coeurs, et je suis là pour les bâtir

Saraç kimi şiirlerde diğerlerinde olduğu gibi dört dizeyi iki dizeye indirmekle birlikte tümce sayısını artırmayı tercih etmiştir. Bu türdeki örnek sayısı bir olup veri tabanımıza 3 numara ile kaydedilmiş şiirlerde gözlenmiştir. 3 numaralı şiirdeki örnek belirgin bir bire çeviri örneği olarak not edilebilir. Çünkü yalnızca yinelemeler değil, vurgulamalar da aynı şekilde aktarılmıştır. Öte yandan aynı dörtlügün üçüncü dizesinde bir olan eylem (yanarım) sayısı, ED’de ikiye çıkarılmıştır (je souffre, je brûle). Diğer bir deyişle, genişletilerek ve belirtikleştirilerek çevrilmiştir:

[35]
a) 'Işkun aldı benden beni
b) Bana seni gerek seni
ab') Ton amour m'a enlevé à moi-même; c'est toi, toi qu'il me faut
c) Ben yanaram düni güni
d) Bana seni gerek seni
cd') Je souffre, je brûle jour et nuit; c'est toi, toi qu'il me faut

\subsubsection{Dört Dize Beş Tümce}

Diğer bir görünüm türü dört dizede beş tümcenin bulunduğu görünümdür. 2, 3, 6, 7, 8 ve 9 numaralı şiirlerde gözlemlenen toplam 12 örnek bu tür görünüme sahiptir. Bunlardan bazıları dolaylı anlatım tümceleri içeren örnekler olup ana tümce eylemi ile aktarılan yan tümce eylemi ayrı ayrı sayılmıştır. Bu örneklerden biri veri tabanımıza 7 numara ile kaydedilen şiirin 2 numaralı dörtlüğüdür. İkinci dizede yer alan dolaylı anlatım ana tümcesi (dersin) ile yan tümcesi (benimdir) dâhil beş tümce içeren dörtlükte iki basit tümce (birinci ve üçüncü dizeler) ile biri dolaylı anlatım, diğeri ise -dIk ilgi adılıyla bağlı olmak üzere iki birleşik tümce yer almaktadır. Saraç birinci dizenin çevirisinde kaynak metne bağlı kalmış olmakla birlikte, ikinci dizeyi çevirirken, dizeyi oluşturan tümceyi participe présent ile önceki tümceye bağlayarak çevirmeyi tercih etmiştir. Bunu yaparken, demek eyleminin kipini ve zamanını değiştirerek penser 
eylemiyle; koşacı (-dIr) dönüşlü eylem s'assurer ile çevirmiş, bu arada toi-même'i eklemiştir. Bu yönüyle çeviri yaklaşımı genişletmeye dayanmakta, fakat bununla sınırlı kalmamaktadır. Çünkü çevirmen aynı zamanda tümcenin ED okuru için belirtikleştirilerek çevrilmesine özen göstermektedir. Buradaki belirtikleştirme yaklaşımı tümcenin önvarsayımı veya sezdiriminin çeviri yaklaşımı olarak benimsenmesine dayanmaktadır. Bir başka anlatımla, çevirmen okur adına iletiyi daha anlaşılır ve açık kılmaya çalışmaktadır:

[36]
a) Dünyaya inanırsın
b) Rizka benimdir dersin
$a b$ ') Tu crois en ce monde pensant que tu t'assures toi-même ta pitance

Saraç sonraki iki dizede yer alan tümcelerin yerlerini değiştirmekte, bunu önceki dize sonunda yer alan pitance ile son dizenin sonunda yer alan immense sözcükleri arasında uyak oluşturmak amacıyla yapmaktadır. Nitekim niçün yalan söylersin gibi bir soru tümcesini c'est ... que ile bilgi yapısını değiştirerek ve ne ... que belirteci ile genişleterek bildirme tümcesine dönüştürmektedir. Ayrıca yalan söylemek eylemini ad öbeği (un mensonge immense) şeklinde aktarmaktadır. Erek metinde ad öbeğinde yer alan immense kaynak metinde bulunmayan bir eklenti olarak not edilmelidir. Saraç'ın kaynak metinde dörtlüğün son dizesiyken yerini değiştirerek öne aldığı hiç sen dediğin olmaz tümcesinin dediğin bölümü bire bir (ce que tu dis) çevrilmiştir, fakat yüklem konumundaki olmaz eylemi sıfata dönüştürülerek (impossible) ED’ye aktarılmıştır. Sıfatın olağan koşullarda être eylemi ile koşaç konumunda kullanılması beklenirken, özne (ce) ve eylem (être) eksiltilmiştir:

[36]
c) Niçün yalan söylersin
d) Hiç sen dediğin olmaz
cd') Impossible ce que tu dis; ce n'est là qu'un mensonge immense

Dört dizenin beş tümce içerdiği örneklerden birçoğu veri tabanımıza iki numara ile kayıtlı şiirin 1, 2, 4, 5 ve 6 numaralı dörtlüklerinde yer almaktadır. Bir numaralı dörtlüğün ilk dizesi ikilemeye dayalı bir yan tümce ile ana tümce içeren birleşik tümce; ikinci dize basit tümcedir. Saraç - (y)A - (y)A ulaciyla oluşturulan yana yana belirteç tümlecini ED'de participe présent ile çevirirken, ana tümcenin karşılığı olarak je ne fais qu'errer'yi önermekte, bunu yaparken ne... que 'yü eklenti olarak kullanmaktadır. İkinci dize et bağlacının eklenmesi dışında bire bir çevrilmiş görünmektedir. Fakat burada diller arası sözlüksel ayrılıktan kaynaklanan bir fark söz konusudur. Türkçede kana boyamak şeklindeki iki öğeli deyim Fransızcada tek bir eylemle (ensanglanter) karşılanmıştır. Bu yönüyle diller arası farklılıktan kaynaklanan bir daraltmadan söz edilebilir:

7 ED metninde "une mensonge" şeklinde geçmekte olup gözden kaçmış bir hata olarak değerlendirilmiştir. Fransızcada mensonge sözcüğü eril olduğundan "un mensonge" şeklinde düzeltilerek verilmiştir. 
[37]
a) Ben yürürüm yana yana
b) Aşk boyadı beni kana
ab') Souffrant je ne fais qu'errer, et l'amour m'a ensanglanté

Dörtlüğün devamında kaynak metinde ne ... ne ... bağlacı ile bağlı koşaç tümcesi yapının bire bir karşılığ 1 olan ne ... ni ... ile karşılanırken Saraç'ın plus belirtecini eklemiş olması dikkat çekmektedir. Çevirmenin bu eklemeyi yukarıdaki dize ile anlamsal bütünlük oluşturmak amacıyla yaptığı düşünülmektedir:

[37]
c) Ne deliyem ne divane
d) Gel gör beni aşk neyledi
cd') Je ne suis plus sage ni fou, voilà où m'a réduit l'amour.

Şiirin iki numaralı dörtlüğünde gâh belirteci ile başlayan ardışık üç tümce ve şiir boyunca yinelenen ve iki tümce içeren nakarat yer almaktadır. Saraç bunların çevirisinde dize sayısını her zamanki gibi ikiye, tümce sayısını da dörde düşürmüştür. Tümcelerin tamamı eylemle (tozaram, eserem, çağlaram) başlamakta ve ilgeç öbeği ile sona ermektedir. Saraç söz konusu tümcelerin çevirisinde bire bir çeviri yaklaşımını benimsemiştir. Nitekim tozmak, esmek ve çağlamak eylemleri için sırasıyla souffler, poudroyer ve couler eylemlerini kullanmıştır. Adlar için aynı yaklaşımın benimsendiği bütünüyle söylenemez, çünkü yel sözcüğünü vent; sel sözcüğünü torrent ile karşılamış olsa da yir sözcüğü için chemin sözcüğünü tercih etmiştir:

[38]
a) Gâh tozaram yirler gibi
b) Gâh eserem yeller gibi
ab') Je souffle tantôt comme les vents, tantôt je poudroie comme les chemins
c) Gâh çaglaram seller gibi
d) Gel gör beni '1şk n'eyledi
cd') tantôt je coule comme les torrents, voilà où m'a réduit l'amour.

Özgün metinde dört dizede dört tümcenin yer aldı̆̆ 1 , ama çevirmenin tümce sayısını üçe düşürerek çevirdiği örneklerden biri yine iki numaralı şiirde gözlenmektedir. Şiirin dört numaralı dörtlügünün ilk üç dizesi sıralı bağlı üç tümce içermektedir. Son dize ise iki sıralı bağlı tümce içermektedir. İlk iki dizedeki tümceler geniş zamanda çekilmiş eylemleri (yürürem; soraram) dişında -dAn ve -(y)A durum ekleri ile oluşturulmuş ikilemeler (ilden ile; dilden dile) içermektedir. Saraç eylemleri bire bir eşdeğerleri (marcher, demander) yerine bağlamsal eşdeğerleri sayılabilecek parcourir ve chercher eylemleri ile çevirirken tümce sayısını korumuştur. Benzer şekilde ilden ile ikilemesi villes et villages bağlı ad öbeği ile dilden dile ikilemesi ise en mille langages ilgeç öbeği ile verilmiştir: 
[39]

a) Ben yürürem ilden ile

b) Dost soraram dilden dile

ab') Je parcours villes et villages, cherche l'Aimé en mille langages

Saraç dörtlüğün üçüncü dizesinde kaynak metinden önemli ölçüde ayrılan sözdizimsel girişimler gerçekleştirmiştir. Bu girişimlerden ilki gurbette ifadesi en terre lointain ilgeç öbeğine dönüştürülmesi olup bire bir çeviri örneği olarak kabul edilebilir. Öte yandan halim kim bile biçimindeki sorunun önvarsayımı veya sezdirimi (hiç kimse bilmez) çeviri tercihi olarak kullanılmıştır. Bu yapılırken bilmek eylemi karşılığında Fransızcada participe passé kipiyle oluşturulmuş inconnu sıfatı tercih edilmiştir. Bu nedenle yapılan işlem eylemin sıfat biçiminde dönüştürülerek çevrilmesi olarak değerlendirilebilir. Bu yaklaşımla ilgili olarak ayrıca tümcenin tümce niteliğinin ortadan kaldırılarak bir önceki tümcenin uzantısı hâline getirildiği not edilmelidir:

[39]

c) Gurbetde halüm kim bile

d) Gel gör beni '1şk n'eyledi

cd') En terre lointaine, inconnu de tous, voilà où m'a réduit l'amour

Tümce sayısının bir eksiltildiği örneklerden biri de yine 2 numaralı şiirde yer almaktadır. Şiirin beş numaralı dörtlügünün ilk üç dizesi biri yalın (iki numaralı dize), diğer ikisi (birinci ve üçüncü) ulaçla (-Ip) bağlı üç tümce içermektedir. Son dizede yer alan iki tümce içeren dizeyle birlikte beş tümce içeren dörtlük ED'de iki dizeye ve dört tümceye indirilerek çevrilmiştir. Saraç bunu yaparken ilk dizede Mecnun oluban (olup) şeklindeki yan tümceyi eylemi eksilterek ilgeç öbeğine dönüştürmektedir. Yürümek eylemini errer eylemi ile karşılayan Saraç ne ... que belirteci ile faire eylemini kaynak metinden farklı olarak eklemektedir. İzleyen dizedeki tümce büyük oranda bire bir çevrilmekle birlikte kaynak metinde olmayan iyelik sıfatı (mon rêve) eklenmekte, kaynak metinde bulunan gösterme sıfatı $o$ ise eksiltilmektedir:

[40]
a) Mecnun oluban yürürüm
b) $\mathrm{O}$ yari düşte görürüm
ab') Je ne fais qu'errer comme Mecnun; je vois l'Ami dans mon rêve

Benzer tümce yapısına sahip üçüncü dizedeki tümcenin çevirisinde hem sözlüksel hem de sözdizimsel olarak kaynak metne bağlı kalındığı görülmektedir. Nitekim kaynak metinde uyanıp şeklinde ana tümceye bağlanan yan tümce erek metinde yapının bire bir karşılı̆̆ sayılabilecek participe passé ile aktarılmıştır. Koşaçlı melül olurum da aynı biçimde kaynak tümcedeki öğelerin ED’deki bire bir karşılığı olan attributif yapı ile çevrilmiştir. Tek farklılık melül sıfatının karşılığı olarak verilen triste'in pekiştirme belirteci tout ile desteklenmiş olmasıdır. Bu girişim bir eklenti girişimi olarak not edilmelidir: 
[40]
c) Uyanıp melül olurum
d) Gel gör beni aşk neyledi
cd') Eveillé, je deviens tout triste, voilà où m'a réduit l'amour

Saraç'ın beş tümceyi iki tümceye indirdiği örneklerden biri yine 2 numaralı şiirde yer almaktadır. Şiirin altıncı dörtlüğü ilk üç dizesi sıralı bağımsız üç tümce içermekte olup bunlar yüklem konumlarındaki -imek iylemi nedeniyle koşaç tümceleridir. Son dizedeki iki tümce de eklendiğinde tümce sayısı beşe çıkmaktadır. Saraç dörtlüğün çevirisinde ilk üç dizeyi tek tümcede birleştirerek eksiltme yoluna gitmiştir. Bunun yaparken koşaç karşılığı olarak geçmiş zaman ortacı (participe passé; infortuné, blessé, tombé loin) kullanmış ve bunları pauvre Yunus biçimindeki ad öbeğinin uzantısı yapmıştır:

[41]
a) Ben Yûnus-1 bî-çâreyem
b) Başdan ayaga yareyem
ab') Pauvre Yunus, infortuné, blessé de la tête aux pieds
c) Dost ilinde âvâreyem
d) Gel gör beni '1şk n'eyledi
cd') Tombé loin de la terre de l'Aimé, voilà où m'a réduit l'Amour

Üç numaralı şiirin dört numaralı dörtlüğü de sözdizimsel düzeyde önemli girişimler içermektedir. KD metninde dört dizede beş tümce bulunurken Saraç ED'de tümce sayısını üçe düşürmektedir. Bunu yaparken birinci dizedeki eylem kümesinde istek kipinde çekilmiş eylem içeren Işkun zincirini üzem biçimindeki tümce participe passé ile bir tür sıfat öbeğine dönüştürülmektedir. Fakat aynı zamanda eylem çatısı edilgen hâle getirilmektedir: énivré par ton vin divin. Söz konusu sıfat öbeği de ayrık sıfat (épithète détachée) şeklinde uzantı olarak bir önceki tümcenin öznesini (je) genişletmektedir. Öte yandan yapılan müdahale kaynak metinle ilişkili görünmemektedir. Bu derin farklılığın, Saraç'ın şiire ait başka bir değişkeyi kullanmış olma olasılığından kaynaklandığı düşünülmektedir. Sonraki dizede yer alan delü olam ve dağa düşem gibi iki sıralı bağlı tümceden ilki aynı yaklaşımla sıfat öbeğine (fou d'amour) dönüştürülerek çevrilmiştir. Bu, istek kipinde çekilmiş koşacın (olmak) eksiltilmesi ile elde edilmiş bir değişikliktir. Buna karşılık, izleyen aynı kipsel özelliklerdeki tümce bire bir çevrilmiş ve subjonctif (dilek kipi; que j’habite) ile karşılanmıştır:

[42]
a) 'Işkun zencîrini üzem
b) Delü olam taga düşem
ab') Fou d'amour, que j'habite monts et vaux, enivré par ton vin divin

Saraç önceki dize için kullandığı bire bir çeviri yaklaşımının aksine sonraki dizede koşaç tümcesini eylem tümcesine dönüştürmüş ve kaynak metinden yapısal olarak belirgin derecede farklı bir erek metin oluşturmuştur: 
[42]

c) Sensin dün ü gün endişem

d) Bana seni gerek seni

cd') Que je pense à toi jour et nuit; c'est toi, toi qu'il me faut!

Dört dizede beş tümcenin yer aldığı diğer bir örnek 2 numaralı şiirde görülmektedir. KD metnindeki ilk dize iki tümce içerirken, diğer üç dize birer bağımsız tümceden oluşmaktadır. Saraç dize sayısını ikiye düşürmüş olmakla birlikte, tümce sayısını korumuştur. Bununla birlikte, Saraç'ın bire bir çeviriden kaçındığı ve sözdizimsel düzeyde önemli girişimler gerçekleştirildiği gözlenmektedir. Bunlardan birinde, n’idem sorusu çevirmen tarafından que sorusuna ek olarak mastar eylem (faire) ile çevrilmiştir. Fransızcada soru sözcüğünün arkasına mastar eklenmesi yoluyla elde edilen sözdizimsel seçenek diller arasındaki farklılıklara dayalı dönüşümler için tipik bir örnek olarak not edilebilir. Aynı dizenin devamındaki tümce olan elim ermez yâre ise Saraç tarafından eksiltili bir yapıyla çevrilmiştir. Bu yapılırken, çekimli eylem (elim ermez) çekimsiz eylem (atteindre) ile karşılanmış, fakat olumsuzluk eylemle birlikte değil, yapıya dışarıdan eklenen impossible sıfatı ile verilmiştir. Olağan koşullarda yüklem konumundaki sıfat kişisiz il ve être eylemi ile birlikte (il est impossible) kullanılmalıyken, çevirmen bu ikisini eksiltmeyi tercih etmiştir. Saraç ikinci dizede yer alan tümcede çatıyı ve eylem türünü ilgilendiren girişimler gerçekleştirmiştir. Çatıya ilişkin girişim KD tümcesindeki edilgen eylem bulunmaz'ın ilgeç öbeği ile karşılanmasına (sans remède) dayanmaktadır. Bunun yapılabilmesi için de zorunlu olarak être attributif eylemi kullanılmıştır:

[43]
a) N'idem elim ermez yâre
b) Bulunmaz derdime çare
ab') Que faire, impossible d'atteindre l'Aimé, ma douleur est sans remède

Dörtlüğün üçüncü dizesinde yer alan oldum ilimden avare şeklindeki tümce Saraç tarafından bire bir sayılabilecek bir yaklaşımla aktarılmıştır. Nitekim eylem zamanı ve kipi olduğu gibi korunmuştur. Bütünüyle bire bir çeviri sayılmasını engelleyen gerekçe sözlüksel tercihlerden kaynaklanmaktadır, çünkü $i l$ sözcügünün karşılığı olarak foyer'nin kullanılmış olması bir tür açımlama olarak kabul edilebilir. Dörtlügüun son dizesinde yer alan soru çevrilirken Saraç'ın geniş zamanı yakın gelecek zamanla karşılamış olması not edilmesi gereken bir tercihtir:
c) Oldum ilimden avare
d) Beni bunda eğler misin
cd') Je suis tombé loin du foyer, vas-tu me lanterner dans ces parages?

Dört dizede beş tümcenin yer aldığı örneklerden biri veri tabanımızda sekiz numara ile kayıtlı şiirin üçüncü dörtlüğünde görülmektedir. Kaynak metinde ilk iki dizesi basit iki tümce içerirken, üçüncü dizede sıralı bağlı iki tümce, son dizede ise -(y)An ilgi adılı ile oluşturulmuş adıl ve tümleç konumunda mastar eylem içeren birleşik tümce bulunmaktadır. Saraç dize sayısını ikiye düşürmüş, fakat tümce sayısını korumuştur. Bir numaralı dizedeki tümceyi erek 
metin tümcesine rester eylemini ekleyerek ve bir şeyde kararl olmak ifadesini avoir l'intention de faire quelque chose şeklinde genişleterek çevirmiştir. İkinci dizede ise Saraç'ın çeviri yaklaşımı dilsel biçimlerin ötesine geçen bir yaklaşımdır. Nitekim çevirmen dizeyi oluşturan tümcenin önvarsayımını veya sezdirimini çeviri yaklaşımı olarak tercih etmiştir. Bu sırada gine belirteci karşılığında sans tarder ilgeç öbeğini, gitmeğe geldim eylem öbeği karşılığında ise plier bagage deyimini kullanmıştır:
a) Benim bunda kararım yok
b) Ben gine gitmeğe geldim
ab') Je n'ai pas l'intention de rester ici, je plierai bagage sans tarder

Saraç üçüncü dizedeki sıralı bağlı tümceleri bire bir çevirmekle birlikte, aralarına ED’de et bağlacını eklemiştir. Son dizedeki satmağa geldim öbeğinden geldim'i eksilten çevirmen, tümleç konumundaki mastar eylemi ED'de ana tümce eylemi olarak çevirmekte, zamanını da gelecek zaman olarak belirlemektedir. Bu yönüyle söz konusu örnek eylem kümesinde geçmiş zamanın gelecek zaman olarak ifade edildiği çarpıcı bir örnek olarak not edilmelidir. Aynı dizede bulunan -(y)An ilgili adılı ile oluşturulmuş yalın ad öbeği alana karşılığında à qui le voudra yapısını kullanmaktadır. Burada dikkat çeken almak eylemi karşılığında vouloir'ın tercih edilmiş olmasıdır. Ayrıca Türkçede -(y)An ilgili adılından kaynaklanan zamana ilişkin belirsizlik Saraç tarafından belirli kılınmakta ve gelecek zaman ile belirtikleştirilmektedir:

[44]
c) Bezirgânım metâim çok
d) Alana satmağa geldim
cd) Je suis commerçant et j'ai des biens; je les vendrai à qui le voudra.

Dört dizede beş tümcenin yer aldığg son örnek 9 numaralı şiirde belirlenmiştir. Şiirin üç numaralı dörtlüğünün ilk dizesi iki sıralı bağlı tümce içermektedir. İkinci dize de bu tümcenin devamı olarak iki çekimli eylemde (yumuşanır; muma döner), dolayısıyla iki tümceden oluşmaktadır. Son iki dize tek bir birleşik tümce içermektedir. Tümcenin öznesi ile diğer tümcedeki kış ad öbeğinin uzantısı (kararmış sarp katı kış) olan kararmış sıfat öbeği de üçüncü dizede, tümce eylemi dördüncü dizede yer almaktadır. Saraç dörtlüğün çevirisinde ilk dizedeki iki tümceyi tek bir tümcede birleştirmeyi tercih etmiştir. Bunu yaparken aşk ve gönül sözcüklerindeki iyelik ekleri ile ilk tümcenin yüklem konumundaki var sıfatçıl yüklemini eksiltmiştir. Bu şekilde elde ettiği un coeur amoureux ad öbeği, sonraki dizede yer alan tümcenin de öznesi yapılmış ve yumşanır eylemi de bu özneye göre bire bir çevrilmiştir. Fakat Saraç ikinci dizede muma dönmek eylem öbeğini ED’de ilgeç öbeğine dönüştürerek karşılamıştır. Çeviri tercihleri sözlüksel düzeyde bire bir olarak değerlendirilse bile sözdizimsel düzeyde aynı şey söylenemez:
a) Aşk1 var gönlü yanar 
b) yumşanır muma döner

ab') Un coeur amoureux brûle, se ramollit comme une cire

Aynı yaklaşım son iki dizede de gözlenmekte olup Türkçe kaynak metindeki eylem tümcesi (benzer) Fransızcaya koşaç tümcesi şeklinde çevrilmiştir. Taş gönüller ve kararmış sarp katı $k \iota s ̧$ ad öbeklerine ilişkin sözlüksel tercihler bire bir çeviri yaklaşımını yansıtmakla birlikte benzemek eyleminin eksiltilerek yerine attributif eylem être' in kullanılmış olması bu düşünceyi ortadan kaldırmaktadır. Eylem öbeğinin ilgeç öbeği şeklinde çevrilmesi önceki örneklerde de görülen bir yaklaşım olarak dikkat çekmektedir:

\section{[45]}
c) Taş gönüller kararmış
d) sarp katı kışa benzer
cd') Les coeurs de pierre sont comme un dur hiver froid

\subsubsection{Dört Dize Altı Tümce}

Dört dizede altı tümcenin yer aldığ 1 örnek sayısı 2 olup yalnızca 6 ve 7 numaralı şiirlerde gözlenmiştir. 6 numaralı şiirin yedi numaralı dörtlüğünün ilk dizesi bağımsız yalın tümce içermektedir. İkinci dize sıralı bağlı iki tümceden oluşurken, üçüncü dizede yine bağımsız bir tümce bulunmaktadır. Son dizede ise ardışık iki bütüncül soru tümcesi yer almaktadır. Saraç ilk dizenin çevirisinde Türkçeye özgü canı esrimek deyimini Fransızcadaki bire bir eşdeğeri sayılabilecek avoir l'âme en extase şeklinde çevirmektedir. Fakat bu sırada kaynak metindeki eylem zamanı olan geçmiş zamanı ED'de şimdiki zamana dönüştürmektedir. Bu dönüştürüm diller arası farklılıktan kaynaklanan zorunlu bir dönüştürüm olarak not edilmelidir. İkinci dizede yoldayım şeklindeki koşaç tümcesi eylemin eksiltilmesine dayalı me voilà en route şeklindeki eksiltili tümceyle aktarılmıştır. Dizenin devamındaki soru tümcesi bire bir çevrilmekle birlikte, tümceler arasına mais bağlacı eklenmiştir:

[46]
a) Esridi Yunus'un canı
b) Yoldayım illerim kanı
ab') Yunus, j'ai l'âme en extase, me voilà en route, mais où sont mes contrées

Üçüncü dizede Yunus düşte gördü seni şeklindeki tümcenin öznesi kaynak metinde üçüncü tekil kişiyken, erek metinde birinci tekil kişiye dönüştürülerek aktarılmıştır. Bu yapılırken moi vurgu adılı ile je özne adılı eklenmiştir. Bu sırada T'düz tümleç kişi adılı ile Tu özne kişi adılının büyük yazılması dikkat çekicidir. Bu uygulama incelenen tüm şiirlerde gözlenen ve dil dışı bir yazım biçimi olarak not edilmelidir. Düşs sözcüğünün KD’de yalın olarak kullanılmış olması, buna karşı1ık çevirmenin erek metinde sözcüğe iyelik sıfatı (mon) eklemiş olması da eklenti olarak görülmektedir. Bu tercihin de erek okur yararına belirtikleştirme örneği olduğu düşünülmektedir. Saraç son dizede yer alan ardışık iki bütüncül soruyu tümce türünü değiştirmeksizin aktarırken, bire bir çeviri yaklaşımını benimsemiştir: 
[46]

c) Yunus düşte gördü seni

d) Saru musun sağlar misın

cd') Moi Yunus, je T'ai vu dans mon rêve, es-Tu malade ou en bonne santé?

Yedi numaralı şiirin beş numaralı dörtlüğü de altı tümce içermektedir. Birinci dize biri emir kipi ikinci tekil kişide (gelin), diğeri istek kipi birinci çoğul kişide (tanış olalım) çekimlenmiş iki sıralı bağlı tümceden oluşmaktadır. İkinci ve üçüncü dizelerde yer alan eylemler (kılalım, sevelim, sevilelim) de istek kipi birinci çoğul kişide çekimlenmiş olup dizeleri oluşturan tümceler sıralı bağlı tümce olarak kabul edilebilir. Üçüncü dizedeki ikinci tümce eylem çatısının edilgen olması nedeniyle diğerlerinden ayrılmaktadır. Son dizedeki tümce ise basit tümce olup eylemi etken çatıda ve geniş zamandadır. Çeviri uygulamalarına gelince, Saraç'ın olasılıkla ED'de (idées; aimés) uyak oluşturma kaygısıyla ikinci dizedeki tümceyi birinci dizeye koyduğu görülmektedir. Yerini değiştirdiği tümcenin sözdizimsel yapısını da değişikliğe uğratmış olan Saraç düz tümleci niteleyen sıfat öbeği ile kılmak eylemi içeren tümcenin çevirisinde Fransızcada koşaçsı bir eylem değil, geçişli eylem (prendre) kullanmıştır. Bu yönüyle görece dar bir eylem öbeği (işi kolay kılmak) daha geniş bir eylem öbeğine (prendre une voie plus simple) dönüştürülmüş ve görece örtük bir ifade belirtik hâle getirilmiştir. Öte yandan, eylemin Fransızcadaki kipi kaynak metindeki istek kipi birinci tekil kişi çekiminin bire bir karşılı̆̆ sayılabilecek olan emir kipi olarak benimsenmiştir. Buradaki çeviri tercihinin bire bir çeviri olarak değil, dolaylı çeviri olarak değerlendirilmesi diller arası farklılıktan ileri gelen adlandırma kaynaklı bir sonuçtur. Nitekim Türkçe dilbilgisinde istek kipi olarak adlandırılan kipsel ulam (birinci çoğul kişi) Fransızcada emir kipi olarak adlandırılmaktadır. KD metninde ilk tümce konumundayken ED'de ikinci sıraya konan tümcedeki basit tümce (gelin) bire bir (venez) çevrilmiştir. Buna karşılık tanış olalım şeklindeki koşaçlı basit tümce geçişli échanger (des idées) eylemiyle çevrilirken çekimli eylem mastar eyleme dönüştürülmüştür. Dolayısıyla söz konusu birimin tümce niteliği ortadan kaldırılarak önceki tümcenin uzantısı hâline getirilmiştir:

[47]
a) Gelin tanış olalım
b) İşi kolay kılalım
ab') Prenons une voie plus simple, venez échanger des idées

KD'deki son tümcenin (dünya kimseye kalmaz) yüklem konumundaki eylem ED'de eksiltilmiştir. Yerine être eylemi ile fidèle sıfatı koşaç olarak kullanılmıştır. Diğer bir deyişle, KD'deki geçişli eylem ED'de attributif eyleme dönüştürülmüştür. Bu girişim aynı zamanda bir belirtikleştirme örneği olarak da değerlendirilebilir. KD’de üçüncü dizede yer alan ardışık iki sıralı bağlı tümce ED’de dizenin sonuna konmuştur. Bu yapılırken (sevelim sevilelim) eylem öbekleri kip ve çatı bakımından aynı şekilde aktarılırken, Saraç iki tümce arasındaki anlamsal mantıksal ilişkiyi belirtikleştirmek üzere donc bağlacını eklemiştir. Dolayısıyla ardışık iki sıralı bağlı tümce ED'de bağlaçla bağlı birleşik tümceye dönüştürülmüştür. 
[47]

c) Sevelim sevilelim

d) Dünya kimseye kalmaz

cd') Le monde n'est fidèle à personne; aimons donc, soyons aimés.

\subsubsection{Dört Dize Yedi Tümce}

Saraç'ın çevirdiği şiirler arasında dört dizede yedi tümcenin yer aldığı tek örnek 2 numaralı şiirin üç numaralı dörtlüğünde belirlenmiştir. KD metninin ilk iki dizesi ya ... ya ... bağlaçları ile bağlı olmasına rağmen her bir tümce içerisinde farklı sayılarda çekimli eylem bulunduğundan, bunlar bağımsız tümce sayılmıştır. Dörtlüğün ilk dizesinde emir kipinde çekilmiş iki eylem (al, kaldur) bulunurken, kaldırmak eylemi çatı bakımından ettirgen olarak sınıflandırılabilmesi nedeniyle dikkate değer bir örnektir. İkinci dizede aynı niteliklerde ettirgen çatıdaki irdürmek eylemi de bu kapsamda değerlendirilmelidir. Dörtlüğün üçüncü dizesinde de her ikisi de ettirgen çatıda ağlatdun ve güldür eylemlerinin bulunduğu sıralı bağlı iki tümce yer almaktadır. Son dizede ise emir kipinde çekilmiş iki eylem (gel gör) ve bildirme kipi geçmiş zamanda çekilmiş eylemek eylemini içeren üç tümce bulunmaktadır. Saraç ilk dizenin çevirisinde KD'deki eylemleri (al kaldır) eksiltirken tümcenin önvarsayımını veya sezdirimini çeviri yaklaşımı olarak kullanmaktadır. Tümcenin çevirisinde çevirmen KD'de yinelenen ya ... ya ... bağlacı yerine ikinci tümcenin başına eklenen $d u$ moins'ı tercih etmiştir. İkinci tümce ise Türkçede yaygın bir kullanıma sahip olan ettirken çatının işlevlerine dayalı bir yaklaşımla aktarılmıştır. Bilindiği gibi ettirgen çatı Türkçede neden olma, izin verme, zorla yaptırma, yardım etme vb. işlevlere sahiptir. Bu şiir bağlamında irdürmek eylemi yardım veya izin verme değerlerinde kullanılmışken, Saraç izin verme değeri üzerinden ED'deki laisser + mastar yapısını tercih etmiştir:
a) Yâ elüm al kaldur beni
b) Yâ asluna irdür beni
ab') Donne-moi une main secourable, du moins laisse-moi te rejoindre

Üçüncü dizede tümcelerin yerlerini değiştiren Saraç bu kez ettirgen çatılı güldürmek eylemini Fransızcada benzer bir yapı olan faire + mastar yapısı ile çevirmiş, bu yönüyle bire bir çeviriden yana tercih kullanmıştır. Öte yandan, çevirmen ağlatmak eylemi için aynı yolu izlememiş, bu kez tümcenin önvarsayımını veya sezdirimini çeviri yolu olarak benimsemiştir. Bundan dolayı KD'de ettirgen çatılı tümcenin düz tümleci konumundaki beni ED'de souffrir eyleminin öznesi konumuna taşınmıştır:

[48]

c) Çok aglatdun güldür beni

d) Gel gör beni '1şk n'eyledi

cd') Fais-moi rire, j'ai trop souffert, voilà où m'a réduit l'amour 


\section{BULGULAR VE TARTIŞMA}

Tahsin Saraç tarafından çevirisi yapılan Yunus Emre şiirlerinden bir bölümü ve tümce düzeyi ile sınırlı olarak gerçekleştirilen betimsel araştırma ile birçok bulguya ulaşılmıştır. Bu bulgulardan bir bölümü şiirin biçimsel yönünü ilgilendirirken önemli bir bölümü eylem kümesi düzeyindeki girişimlere ilişkindir. Aşağıda bunlar ana çizilgileriyle sunulmaktadır.

Saraç'ın çeviri yaklaşımına ilişkin bulgulardan ilki şiirlerin biçimsel yönüyle ilgilidir. Bu noktada çevirmen kaynak metinde iki ya da dört dize içeren tüm şiirleri iki dize şeklinde çevirmeyi tercih etmiştir. Ancak hemen belirtmek gerekir ki bu durumun çevirmenin tercihi mi yoksa elindeki kaynak metnin özgün hâlinden mi kaynaklandığı bilgisine erişilememiştir. Saraç da bu konuda kitapta herhangi bir açıklamaya yer vermemiştir. Ancak bu durumun, birçok kaynakta Yunus Emre'nin şiirlerinin çok farklı değişkelerinin bulunuyor olmasından ileri geldiği düşünülmektedir.

Veri tabanımızda yer alan şiirlerin biçimsel boyutuna ilişkin diğer bir bulgu uyaklara ilişkindir. Saraç kaynak şiirlerin tamamında yer alan uyakların önemli bir bölümünü eksiltmek durumunda kalmıştır. Bu da çevirmenin, şiirlerin biçimsel boyutundan çok ileti ve anlam boyutuna odaklandığını göstermektedir. Bununla birlikte, çevirmen sayıca az olmakla birlikte kimi ED metinlerinde uyak oluşturmayı başarmıştır. Öreğin, veri tabanındaki 9 numaralı şiirde bu çaba görülmekte, ilk dizenin son sözcüğü soleil ile ikinci dizenin son sözcüğü pareil arasındaki ses benzerliğine dayalı uyak bulunmaktadır. Bu amaçla Fransızcada pek rastlanmayan bir yaklaşımla sıfat tümleci (à la pierre) eylem öbeğinin başına taşınmıştır [28cd']. Bunun dışında, souterrains / humain [2abcd']; pitance / immense [36abcd']; indispensable / impensable [32abcd'] gibi uyaklar da belirlenmiştir.

Saraç'ın, şiir çevirilerinde sözdizimsel düzeyi ilgilendiren girişimlerine gelince, bunlardan ilki kaynak metindeki eylemin kipinin değiştirilmesine dayanmaktadır. Bu değişiklik, kaynak metin tümcesinde yüklem konumunda bildirme kipindeki bir eylemin ED'de emir kipine; kaynak metin tümcesinde mastar durumundaki bir eylemin bildirme kipine; istek kipindeki bir eyleminse participe passé’ye vb. dönüştürülmesi şeklinde olabilmektedir.

KD'deki bildirme kipinin ED'de emir kipine dönüştürülmesi [24cd']'de gözlenmiş olup Saraç üçüncü dizedeki koşul tümcesi (c) ile sonraki dizedeki sonuç tümcesini (d) ayırma yolunu benimsemiştir. Görünüşte yalnızca biçimsel bir girişim olduğu izlenimi edinilse de gerçekte anlamsal bir girişim de söz konusudur. Nitekim bu ilişkiyi belirginleştirmek üzere tümceler arasına sinon (yoksa) belirteci eklenmiştir. Bu tercih çevirmen tarafından zorunlu olarak yapılmış değildir, çünkü KD'deki koşul tümcesini ED'de de oluşturmak ve bire bir çevirmek mümkündür. Öyleyse çevirmenin bu tercihi yapmaya iten değişken nedir? Birinci gerekçe olarak sözcüksel düzeydeki kültürel öğelerin (eri hak bilmek; abes yere yelmek) ED'de belirtik kılınması kaygısı akla gelmektedir. Ancak bu haklı bir gerekçe değildir, çünkü nihayetinde aynı sözcükler kullanılacak ve sözdizimsel yapı korunacaktır. Bu durumda, bir koşul tümcesini iki ayrı tümce olarak ifade ederek çevirmek ile bire bir çevirmek arasındaki 
tercih seçimlik bir tercihtir. Fakat yine de çevirmenin izlediği yolu belirgin bir biçimde betimlemekte ve gerçekten ne yaptığını anlamakta yarar var. Bu konuya tartışma ve sonuç bölümünde tekrar dönülecektir.

Saraç'ın sözdizimsel düzeyi ilgilendiren ve eylem kipini dönüştürmeye dayanan bir başka girişimi [25ab']'de görülmekte olup emir kipinde çekilmiş eylem (var bin hacca) bildirme kipine dönüştürülmektedir. Çevirmen bununla da yetinmemekte, eylem zamanını gelecek zaman olarak belirlemektedir. Tümcedeki bir öğeyi (gerekse) de eksilten Saraç gerek 4.3.1'de gerekse de burada aynı çeviri yaklaşımını benimsemektedir.

Sözdizimsel düzeyi ilgilendiren diğer bir girişim türü mastar hâldeki eylemin çekimli bir eyleme dönüştürülmesidir. Bu girişimin örnekleri olarak çevirmen KD'de mastar hâldeki eylemi ([23cd]; [24cd]) ED' de bildirme kipindeki bir eylemle çevirmektedir. Benzer girişimlerden biri olarak, Türkçe KD'de [25cd'] mastar hâldeki eylemi mastar hâlde çevirmesine dayanmakla birlikte, tümce yapısı dilsel farklılıklara bağlı olarak ED'de zorunlu olarak dönüştürülmektedir. Nitekim Fransızcada üçüncü tekil kişi adılı il ile falloir, valoir eylemlerinin kullanımına dayanan kişisiz tümce biçimi sıklıkla kullanılmaktadır. Saraç [25cd']'de hepsinden eyice bir gönüle girmektir şeklindeki koşaç tümcesinin çevirisinde bu yolu benimsemiştir.

Saraç'ın KD’deki bir tümceyi ED'de sıfat öbeğine dönüştürerek çevirdiği de görülmektedir. Bu tür örneklerden bir bölümü [42ab'] KD'de eylem öbeğinin başı -imek eyleminin eksiltilerek ED'de participe passé ile oluşturulmuş sıfat öbeğine dönüştürülmesine dayanmaktadır. Bir bölümü ([36ab']; [39cd']; [41cd']; [43ab']) ise aynı eylemin eksiltilmesine ek olarak başka türetim süreçleri ile oluşturulmuş sıfatlar (fou, impossible vb.) ile çevrilmektedir.

Saraç'ın kip düzeyindeki bir diğer girişimi KD'de bildirme kipindeki bir eylemin ED'de participe présent'a dönüştürülerek [36ab'] çevrilmesine dayanmaktadır. Bu girişim bağımsız iki tümceden birinin çevirmen tarafından ana tümce olarak belirlenmesi, buna bağlı olarak diğer tümcenin bağlı yan tümceye dönüştürülmesi ile sonuçlanmaktadır. Dolayısıyla, aslında iç içe geçmiş birçok işlemi içermekte ve sonuç olarak KD' deki tümcenin tümce konumundan çıkarılması ile sonuçlanmaktadır. Çünkü yan tümce olarak adlandırılmasına rağmen aslında bu tür bağlı yan tümceler belirteçlerin gördüğü görevleri yerine getirmektedir.

Saraç'ın çevirici sürecinde başvurduğu yollardan biri de tümcenin ada dönüştürülmesidir. Nitekim niçin yalan söylersin şeklindeki KD tümcesi ce n'est là qu'un mensonge immense şeklinde ad olarak ED'ye aktarılmıştır [36cd'].

Saraç KD'deki tümcelerden bazılarını da ilgece dönüştürerek ED’ye aktarmaktadır [36ab']. Nitekim gözlemlediğimiz örnekteki Mecnun oluban yürürüm ifadesindeki ulaçla bağlı bölüm comme Mecnun şeklinde ilgeç öbeğine dönüştürülmüştür. Bu tür girişimler ayrıca [16ab']'de; [26cd']'de; [27cd']'de; [34cd']'de; [34ab']'de; [38ab']'de; [44ab']'de ve [45abcd']'de gözlenmiştir. Süreç genellikle ulaçla bağlı yan tümcenin koşacı olmak'ın eksiltilmesine ve comme, en, sans, devant, dans gibi ilgeçlerin eklenmesi şeklinde yürümektedir. 
Eylem türünün değiştirilmesi genellikle sözdizimsel düzeyde bir girişim ile sonuçlanmaktadır. Nitekim geçişli bir eylemin geçişsiz bir eylemle ya da geçişli veya geçişsiz bir eylemin koşaç ile değiştirilmesi tümce yapısında değişikliği zorunlu kılmaktadır. Örneğin geçişli bir eylemken Özne + Tümleç + Yüklem dizilişindeki bir tümce Özne + Koşaç + Tümleç dizilişinde bir tümceye dönüşebilmektedir. İncelenen şiirlerde bu dönüşümleri içeren örneklerle de karşılaşılmıştır.

Saraç'ın girişimlerinden biri de görünüşte yalnızca eylem türünü değiştirmeye dayanıyor olsa da aslında tümce düzeyinde değişikliklere yol açan koşaç (-imek, olmak) yerine geçişli eylem (prendre, penser comporter vb.) kullanma ([6]; [23cd']'de; [47ab']; [36cd']) girişimidir. [36cd']'de bu girişimin en belirgin örneklerinden biri yer almakta, sensin dün ü gün endişem şeklindeki tümce que je pense à toi jour et nuit şeklinde ED'ye aktarılırken yine iç içe geçmiş birçok dönüşüm dikkat çekmektedir. [26ab']'deki yavu kıldım ben yoldaşı tümcesinde yer alan geçişli eylem yavu kılmak Fransızcaya perdre eylemi ile çevrilirken aslında koşaç yerine geçişli bir eylem konmaktadır.

Yukarıda bir örneğini verdiğimiz koşacın geçişli eylemle çevrilmesi yaklaşımının tersi de söz konusu olabilmektedir. Nitekim [45cd']'deki taş gönüller kararmış sarp katı kışa benzer şeklindeki tümcede yer alan benzemek geçişli eylemi ED’ye koşaç (être) ile çevrilmiştir. Benzer dönüştürümler [1abcd']'de; [2abcd']'de; [47cd']'de ve [47cd']'de gözlemlenmiştir.

İncelediğimiz şiirlerde istek kipinin sıklıkla kullanıldığı görülürken, Saraç’ın da büyük ölçüde Türkçeye özgü bu kipin çevirisinde farklı tercihler kullandığı gözlemlenmiştir. Bu tercihlerden ilki eksiltmeye dayanmaktadır. [42ab']'de ışkın zencirini üzem deli olam şeklindeki bağımsız tümcelerden ilki sıfat öbeği (fou d'amour) ile ikincisi ise participe passé şeklindeki énivré par ton vin divin edilgen yapıyla çevrilmiştir. Örnek bu yönüyle hem çatı hem de kip ulamlarını ilgilendirmektedir.

İstek kipinin yer aldığ 1 diğer bir örnek [43ab']'de yer almaktadır. N'idem şeklindeki soru tümcesi Fransızcaya özgü bir soru biçimi olan soru sözcüğüne ek olarak mastarın kullanıldığ eksiltili soru ile çevrilmiştir. Saraç istek kipindeki eylemlerin bazılarının çevirisinde [47ab'] ise bire bir çeviri yaklaşımını benimsemiştir.

Sözdizimsel düzeyi etkileyen diğer bir ulam çatı ulamı olup Saraç bu düzeyde de önemli girişimlerde bulunmuştur. Bunlardan biri [26ab']'de yer alan onulmaz bă̆rımın başs şeklindeki tümcedir. Saraç tümcenin çevirisinde edilgen çatıdaki eylemi sıfata dönüştürmektedir. Dolayısıyla geçişsiz bir eylem olarak onmak edilgen çatıdayken sıfat şeklinde (inguérissable) çevrilmiştir.

Saraç'ın belirgin çatı dönüştürümlerinden biri [48cd']'de yer almaktadır. Aynı dizede sıralı bağlı olarak yer alan ettirgen çatıdaki iki eylemden ikincisini (güldür beni) bire bir çevirmeyi (fais-moi rire) tercih eden Saraç ikincisinde farklı bir yol izlemiştir. Nitekim çok ağlatdun tümcesinin düz tümleci ben ED'de özne konumuna getirilirken, özne sen bütünüyle eksiltilmiştir. Sonuç olarak tümce bütünüyle ters yüz edilmiştir. 
Saraç'ın başvurduğu tümce düzeyindeki çeviri yaklaşımlarından biri de tümcenin görünen değil, görünmeyen anlamından (önvarsayım, sezdirim, yan anlam vb.) hareketle bir çeviri önermeye dayanmaktadır. Bu türdeki örnekler ([31ab'; cd']; [32cd']; [36ab']; [39cd']; [40ab']; [48abcd']) tümce yapısının, kimi zaman da türünün bütünüyle değiştirilmesi ile sonuçlanmaktadır. Nitekim [39 cd']'de gurbette halim kim bile soru tümcesi, tümce niteliği ortadan kaldırılarak ilgeç öbeği şeklinde çevrilirken, sorunun kendisi değil, bilinen yanıtı (kimse bilmez) çeviri seçeneği olarak kullanılmıştır. Bu açıdan, çevirmen okurun bu sorudan bir şey anlamayacağı düşüncesi ve okur yararına anlamı berraklaştırma kaygısıyla hareket etmekle birlikte, bu tercihin doğru olup olmadığı tartışılmaktadır. Fakat bunun da bir çevirmen kararı olduğu ortadadır.

Saraç benzer bir tercihi [44ab']'de yapmış, benim bunda kararım yok tümcesini bire bire yakın bir yaklaşımla çevirmesine rağmen bir yerde kararı olmak eylemini ED'de kalmak (rester) eylemini ekleyerek belirtik kılmıştır. İkinci dizedeki ben yine gitmeye geldim tümcesi belirgin bir uzlaşımsal sezdirim örneği olarak yine belirtecini içermektedir. Çevirmen buradan hareketle sözceden çıkarılabilecek olası anlamlardan biri olan je plierai bagage sans tarder (çok geçmeden toplayacă̆ım tası tară̆ı) tümcesini tercih etmiştir.

Yukarıda çatıyı ilgilendiren girişimler arasında yer verdiğimiz örnekler [48abcd'] yalnızca biçimsel düzeyi değil, anlamsal ve edimbilimsel düzeyi de ilgilendiren örnekler olarak değerlendirilebilir. Nitekim elim al kaldır beni yerine donne-moi une main secourable çeviri önerisi tümcenin eğretilemeli anlamına dayanmaktadır. Buna karşılık çok ăglattın yerine j'ai trop soufert çeviri önerisinin kullanılması bir yandan tümcedeki rolleri baştan aşağı değiştirmeye bir yandan da tümce yapısını değiştirmeye dayalı olarak belirtikleştirme örneği olarak karşımıza çıkmaktadır.

Aynı dörtlükteki [48cd']'de yer alan gel göre beni tümcesinin bütünüyle eksiltilmesi ve yerine voilà belirtecinin kullanılması daraltmaya dayanmasına rağmen ED okuru için belirtikleştirme örneğidir. Saraç bu yaklaşımı son dizede de kullanmıştır. Fakat burada, aşk beni neyledi sorusundaki ne yapmak sorusu yerine où m'a réduit l'amour (aşk beni nereye indir(ge)di) sorusu tercih edilmiştir. Buradaki tercih aynı zamanda yanıtı bilinen sorunun, bilinen yanıtının çeviri tercihi olarak kullanılmasıdır.

\section{SONUÇ}

Çevirinin genel güçlüklerinin yanı sıra, şiir çevirisine özgü olanlar da düşünüldüğünde, anadilinden Fransızcaya Yunus Emre gibi bir şairin şiirlerini çevirmek cesaret isteyen bir girişimdir. Bu açıdan Tahsin Saraç ağır bir görevi üstlenmiş ve gereğince yerine getirmiştir. Çeviri stratejileri açısından değerlendirildiğinde, çevirmen gerektiğinde bire bir, gerektiğinde dolaylı çeviri stratejilerine başvurmaktan çekinmemiştir. Bu genel özgürlük deneyimli bir yazın insanı ve şair olmasının yanı sıra, Türkçede ve Fransızcada yetkinliğin de bir sonucu olarak değerlendirilebilir. Nitekim tümce düzeyiyle sınırladığımız bu çalışmada Saraç'ın dize sayısını ve tümce sayısını bir sınırlama ölçütü olarak görmediği gözlemlenmiştir. Bu 
doğrultuda uyakları büyük ölçüde göz ardı etmiş olmasına karşın, bunun Yunus şiirlerindeki evrensel felsefeyi ED’ye aktarma kaygısından kaynaklandığg anlaşılmaktadır. Kaldı ki şiirlerin bazılarında uyakları da vermeyi başarmıştır.

Çeviri stratejisi kavramı çeviri sürecinde tanımlanabilecek, hatta tanımlanması gereken bir kavram olmasına karşın, içinde belirsizlikler barındıran bir kavramdır. Doğrudan ya da dolaylı çeviri stratejisi şeklinde ayrı ayrı başlıklar altında sunulan stratejilerin özellikle Türkçe ve Fransızca gibi yapısal farklılıkları belirgin diller söz konusu olduğunda kesin sinırlarla birbirlerinden ayrılamayacağı görülmektedir. Kuşkusuz bu da şaşırtıcı bir durum değildir, çünkü çevirmenin çeviri edimi sırasında yaptığı işlemleri tanımlamak kolay değildir. Bu güçlük çevirmenin karmaşık bir dizge olan dil göstergesi ile oluşturulmuş iletileri işlemlemeden geçiriyor, parçalıyor ve yeniden oluşturuyor olmasından kaynaklanmaktadır. Dolayısıyla, çok sayıda değişkeni iki dil dizgesinde ve aynı anda göz önünde bulundurmaktadır. Bunun bir sonucu olarak sözcüksel düzeyi ilgilendiriyormuş gibi görünen bir girişim aslında öbeği ve hatta tümcenin tamamını ilgilendiren bir ürün ile sonuçlanabilmektedir.

Çevirmenin temel kaygıları KD ile ED girdilerinin anlamsal denkliğidir. Öte yandan bu denkliği sağlarken diller arası farklılıklardan kaynaklanan zorunlu biçimsel eksilme ve artmalar gerçekleşmektedir. Bu noktada çevirmen için temel belirleyici ED’de yeniden kurguladığı metnin KD'dekine denk bir metinsellikle aktarıldığından emin olmaktır. Bu çaba örneğin ilk dizenin yazılmasından sonra ikincinin nasıl olması gerektiğini de belirleyen bir sınırlılıkta gerçekleşir. Nitekim çevirilerde Saraç'ın şiirin dörtlüklerine bir bütün olarak yaklaştığını gösteren tercihlerle karşılaşılmıştır. Tümcenin ad öbeği, sıfat öbeği veya ilgeç öbeği şeklinde çevrilmesi bu tercihin bir yansımasıdır. Benzer şekilde Saraç'ın, gerektiğinde tümcenin önvarsayımı ile sezdirimini bir çeviri yöntemi olarak benimsemiş olduğu görülmüştür. Diğer bir deyişle, tümcenin görünmeyen ve çıkarıma dayalı anlamını bir çeviri seçeneği olarak değerlendirmekten kaçınmamıştır.

Çeviri stratejisi kavramı çeviri sürecini bütünüyle açıklamaya yetmemekle birlikte, çevirmen eğitiminde çevirmen adaylarına öğretilmesi gereken bir kavramdır. Özellikle belli bir çeviri ürünü ile ona kaynaklık eden girdiyi karşılaştırabilmek ve çevirmenin ne tür tercihlerde bulunduğunu ve bu tercihlerin gerekçelerini belirleyebilmek, genç çevirmenlerden beklenen bir beceri olmalıdır. Özellikle deneyimli çevirmenlerin çeviri yaklaşımları genç çevirmenlere bu açıdan yol gösterici olabilir.

Hakem Değerlendirmesi: Dış bağımsız.

Çıkar Çatışması: Yazar çıkar çatışması bildirmemiştir.

Finansal Destek: Yazar bu çalışma için finansal destek almadığını beyan etmiştir.

Peer-review: Externally peer-reviewed.

Conflict of Interest: The author has no conflict of interest to declare.

Grant Support: The author declared that this study has received no financial support. 


\section{KAYNAKÇA/REFERENCES}

Andrei, C. (2014). Vers la maîtrise de la traduction littéraire - guide théorique et pratique -. Galati: Galati University Press.

Arıkan, R. A. ve Temur, N. (2019). Talât Sait Halman'ın Yunus Emre şiirlerinin İngilizce çevirileri üzerine bir inceleme. International Journal of Human Studies 2(4), 148-161. https://doi.org/10.35235/uicd.565461

Baker, M. (1992, 2011). In other words. New York: Routledge.

Ballard, M. (2006). À propos des procédés de traduction. Revue de traduction Palimpsestes. Özel Say1, 113-130. https://doi.org/10.4000/palimpsestes.386

Cary, E. (2012). Nasıl çevirmeli? Çeviri olanaklı mıdır? (M. Rifat ve S. Rifat, Çev.) M. Rifat (Haz.) Çeviri Seçkisi II Çeviri(bilim) Nedir? (s. 55-60). İstanbul: Sel Yayıncıl1k.

Coşkun, O. (2018). Yunus Emre şiirlerinden Fransızca'ya uyarlamalar üzerine genel bir değerlendirme: Yves Régnier'den uyarlamalar. Turkophone 5(3), 38-55. Erişim adresi: https://dergipark.org.tr/tr/pub/ turkophone/issue/41938/506315

Etkind, E. (1982). Un art en crise, essai de poétique de la traduction poétique. Lausanne: L'Age de l'Homme.

Eyuboğlu, S. (2003). Sanat üzerine denemeler. M. Rifat (Haz.) Çeviri Seçkisi I, Çeviriyi Düşünenler (s. 119-121). İstanbul: Dünya Yayıncılık.

Gürbüz, S. ve Şahin, F. (2015). Sosyal bilimlerde araştırma yöntemleri. Ankara: Seçkin.

Guidère, M. (2016). Introduction à la traductologie: Penser la traduction: hier, aujourd'hui, demain. Louvain-la-Neuve: De Boeck Supérieur s.a.

Börekçi, G. (2015, 1 Şubat). Talat Sait Halman: "Shakespeare çevirileriyle o kadar ıstırap çektim ki cennette bir yer kazanmışımdır”. Aralık [Web log post]. egoistokur.com: https://egoistokur.com/ne-bir-cevirikurami-yarattik-ne-ceviri-elestirisi-yapabildik/ adresinden alındı.

Henry, J. (2003). La traduction des jeux de mots. Paris: Presse Sorbonne Nouvelle.

Köksal, D. (2008). Çeviri ĕgitimi kuram ve uygulama. Ankara: Nobel.

Mounin, G. (1963). Les problèmes théoriques de la traduction. Paris: Éditions Gallimard.

Newmark, P. (1988). A textbook of translation. Shangai Foreign Language Education Press.

Paz, O. (2012). Söz sanatı ve söze bağlılık açısından çeviri. M. Rifat (Haz.) Çeviri Seçkisi II Çeviri(bilim) Nedir? (s. 97-106). İstanbul: Sel Yayıncilık.

Raková, Z. (2016). Çeviri kuramları (Y. Polat, Çev.). Ankara: Çevirmenin Yayını.

Rifat, O. (2003). Şiir konuşması. M. Rifat (Haz.), Çeviri seçkisi I, çeviriyi düşünenler (s. 122-126). İstanbul: Dünya Yayıncılık.

Saraç, T. (1973). Yunus Emre, Poèmes. (T. Saraç, Çev.) Ankara: Ministère du Tourisme et de l'Information de Turquie.

Tatc1, M. (2012). Dîvân-ı Yûnus Emre. Türkiye Diyanet Vakfi.

Tuncel, B. (1971). Fransızca'da Yunus Emre. Ankara: Basnur Basımevi.

Vinay, J.-P., \& Darbelnet, J. (1995). Comparative stylistics of french and english. A methodology for translation. Amsterdam/Philadelphia: John Benjamins B. V.

Yazarsız. (tarih yok). Yunus Emre divanı-seçmeler-. Altın Kitaplar. 
